\title{
Conduit system, degassing, and flow dynamics of a rhyolite lava: A case study of the Shiroyama lava on Himeshima Island, Japan
}

\author{
Kuniyuki Furukawa ${ }^{\star \alpha}$, Koji Uno ${ }^{\beta}$, Yu Horiuchi ${ }^{\gamma}$, Shintaro Murohashi ${ }^{\beta}$, Motohiro Tsuboi $^{\delta}$ \\ ${ }^{\alpha}$ Faculty of Business Administration, Aichi University, Japan. \\ ${ }^{\beta}$ Department of Earth Sciences, Okayama University, Japan. \\ $\gamma$ Oita Himeshima Geopark Promotion Office, Japan. \\ ${ }^{\delta}$ Department of Applied Chemistry for Environment, School of Science and Technology, Kwansei Gakuin University, Japan.
}

\begin{abstract}
This study presents a description of a rhyolite lava-forming eruption, including the conduit system, degassing history during the lava flow dynamics. We examined the Pleistocene Shiroyama rhyolite lava on Himeshima Island, Japan. The lava is mainly characterized by locally developed obsidian. Based on the structural variation, the obsidian lithofacies correspond to the shallow conduit. The geological investigation and FTIR analyses showed that gas removal from the conduit magma proceeded via vesiculation, fracturing, and brecciation, allowing formation of the dense obsidian. Since the lava originally maintained some extent of water, the lava effervesced just after the effusion. This vesiculation resulted in pervasive bubble coalescence and the formation of abundant permeable pathways. The volcanic gasses escaped via those pathways, allowing collapse of the bubbles and deflation of the lava. AMS (anisotropy of magnetic susceptibility) results indicate that the lava spread concentrically.
\end{abstract}

Keywords: Obsidian; Flow banding; FTIR; AMS; Pumiceous

\section{InTRODUCTION}

Effusion of lava has resulted in various volcanic disasters that frequently lead to severe damage to houses, farms, and traffic networks. To understand the potential hazards, the eruption, degassing, and flow dynamics of lavas have been continuously studied. Volcanic hazards associated with lavas are usually diversified owing to the effect of composition on magma properties. In basaltic, andesitic, and dacitic lavas, there have been many opportunities for the direct observations, and their eruption, flow dynamics, and potential hazards are relatively well understood [e.g. Gregg 2017; Nakada et al. 2019]. However, it seems to be difficult for volcanologists to predict the flow behavior and the envisaged hazards precisely during effusion of rhyolite lava. This is because rhyolite lava effusion has rarely been directly observed, and little is known about its lava emplacement. The direct observations of rhyolite lavas are restricted to the 2008 eruption of Chaitén volcano [Castro and Dingwell 2009; Lara 2009] and the 2011-2012 eruption of Cordón Caulle volcano [Schipper et al. 2013; Tuffen et al. 2013]. These events have provided limited but valuable opportunities for understanding rhyolite lavas [Farquharson et al. 2015; Magnall et al. 2018; Schipper et al. 2013; Tuffen et al. 2013]. Because these are infrequent events, investigation has instead generally relied on the exposure of dissected lavas and conduits, or a combination of numerical and

\footnotetext{
*Corresponding author: kfuru@vega.aichi-u.ac.jp
}

experimental work.

Non-explosive silicic volcanism, which often manifests as obsidian lava [e.g. Sano et al. 2015; Shields et al. 2016; Tuffen et al. 2013], has been considered to require sufficient outgassing during magma ascent, and the outgassing mechanism has been controversial. Taylor et al. [1983] and Eichelberger et al. [1986] explain how the connected bubbles formed during magma ascent act as a permeable network through which volatiles escapes, and the foam collapses to produce a dense lava. Castro et al. [2014] and Cabrera et al. [2015] proposed that degassing and outgassing occur via transient fracturing networks formed in the magma during ascent, and the fractures heal to form a dense lava. Wadsworth et al. [2020] recently suggest that rhyolitic magma generally fragments during ascent through the upper crust and that effusive eruptions result from conduit blockage and sintering of the pyroclastic products of deeper cryptic fragmentation. The silicic conduit structure has been revealed via investigation of spines and dissected conduits and is likely composed of the fault gouge zone, cataclastic and sheared zone, and massive zone from outer to center [Pallister et al. 2012]. Erupted rhyolite lavas usually show complex internal structures, and the development processes have been studied [e.g. Furukawa et al. 2019; Manley and Fink 1987; Stevenson et al. 1994]. Fink and Manley [1987] and Manley and Fink and Manley [1987] classified the vertical structural variation of a rhyolite lava in terms of the vesiculation and cooling processes into finely vesicular pumice (FVP), dense obsidian (OBS), diapiric coarsely vesicu- 


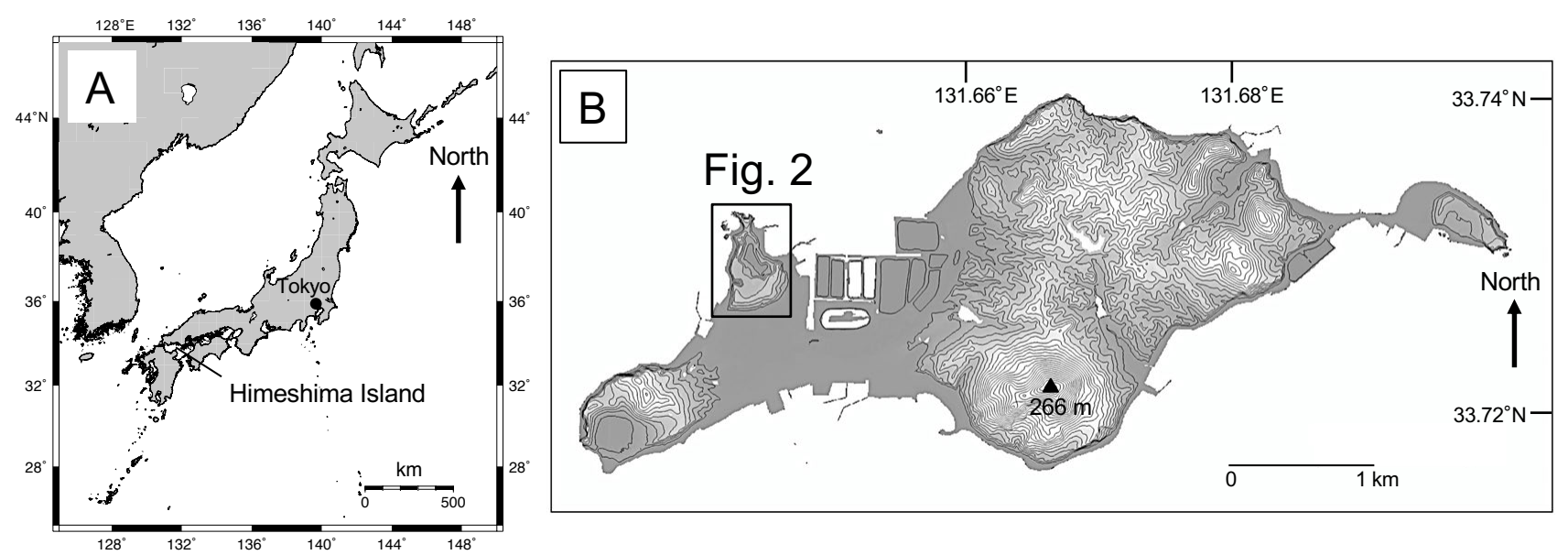

Figure 1: [A] Map of Japan and the adjacent area. [B] Topographic map of Himeshima Island.

lar pumice (CVP), and crystalline rhyolite (RHY) from upper to center. Formation processes of surface ogives [e.g. Andrews et al. 2021; Fink 1980] and spherulites in obsidian lithofacies [e.g. Furukawa et al. 2019; Watkins et al. 2008] of rhyolite lavas have also been discussed. Potential hazards such as surface explosions and flow front collapses have also been pointed out from ancient rhyolite lavas [Castro et al. 2002a; Fink and Manley 1987]. Because such hazards are potentially caused by the overpressure of inner volcanic gasses, the degassing and outgassing systems of rhyolite lavas have been examined [Furukawa et al. 2010; Ryan et al. 2019; Shields et al. 2016]. The flow dynamics of rhyolite lavas have been deduced by researchers based on textural analyses, magnetic experiments, and numerical studies [Bullock et al. 2018; Castro et al. 2002a; Furukawa and Uno 2015; Magnall et al. 2017].

We examined Shiroyama rhyolite lava [Itoh 1989] on Himeshima Island, SW Japan (Figure 1). The lava is characterized by the presence of obsidian, whose exposure is restricted in the Kannonzaki area (Figure 2A). An accurate feeder of Shiroyama lava was not previously identified, but our geological investigation revealed that the obsidian lithofacies correspond to the shallow conduit. This means that Shiroyama lava is observable from the conduit to its distal extent. Because of those good exposures, the rhyolite lava emplacement can be revealed via studies of Shiroyama lava. Here, we examined the geological characteristics, densities, water contents, and magnetic characteristics of Shiroyama lava and discussed the conduit system, eruption, degassing history during the lava flows, and flow dynamics.

Obsidian in Shiroyama lava will make a significant contribution to volcanology as well as archeology. Stone tools made from the obsidian in the prehistoric period have been widely excavated in southwestern Japan. Due to its high natural and cultural value, the Kannonzaki area (Figure 2A), which includes the obsidian site, has been designated as a national natural monument. It is used for education and tourism as a geopark site. Owing to this designation, the rocks, animals, and plants are strictly protected in the Kannonzaki area. Thus, we conducted a non-destructive survey there.

\subsection{Geological setting}

Himeshima Island is located in the north of the Kyushu area in SW Japan (Figure 1). The island is mainly composed of seven Pleistocene volcanoes called the Himeshima volcanic group [Kasama and Huzita 1955], characterized by silicic magmatism of $65-75 \mathrm{wt} . \% \mathrm{SiO}_{2}$ [Itoh 1990]. The magmas were generated by the subduction of the Philippine Sea Plate. The Himeshima volcanic group is underlain by lower to middle Pleistocene sediments, comprising the Maruishibana formation, Kawashiri gravel bed, and Karato formation in chronological order [Itoh et al. 1997; Kasama and Huzita 1955]. The sediments characteristically contain rounded andesite clasts, which are considered to be derived from the adjacent Early Pleistocene Futago volcanic group via a fluvial system [Itoh 1989].

\subsection{Shiroyama lava}

Shiroyama lava is part of the Shiroyama volcano (Figure 2), which is located in the western part of Himeshima Island. The lava is characterized by the presence of obsidian. Several ages for the lava have been reported using various methods.

Kaneoka and Suzuki [1970] reported lava ages $0.32 \pm$ $0.05 \mathrm{Ma}$ and $0.34 \pm 0.05 \mathrm{Ma}$ based on K-Ar and fission track datings, respectively. Kamata [1988] reported an age of $0.2 \pm 0.1 \mathrm{Ma}$ based on $\mathrm{K}-\mathrm{Ar}$ dating. Matsumoto et al. [2010] reported an age of $0.104 \pm 0.007$ Ma based on Ar-Ar dating. The ages correspond to the Chibanian age (middle Pleistocene) or the Upper Pleistocene. An accurate feeder of Shiroyama lava was not previ- 


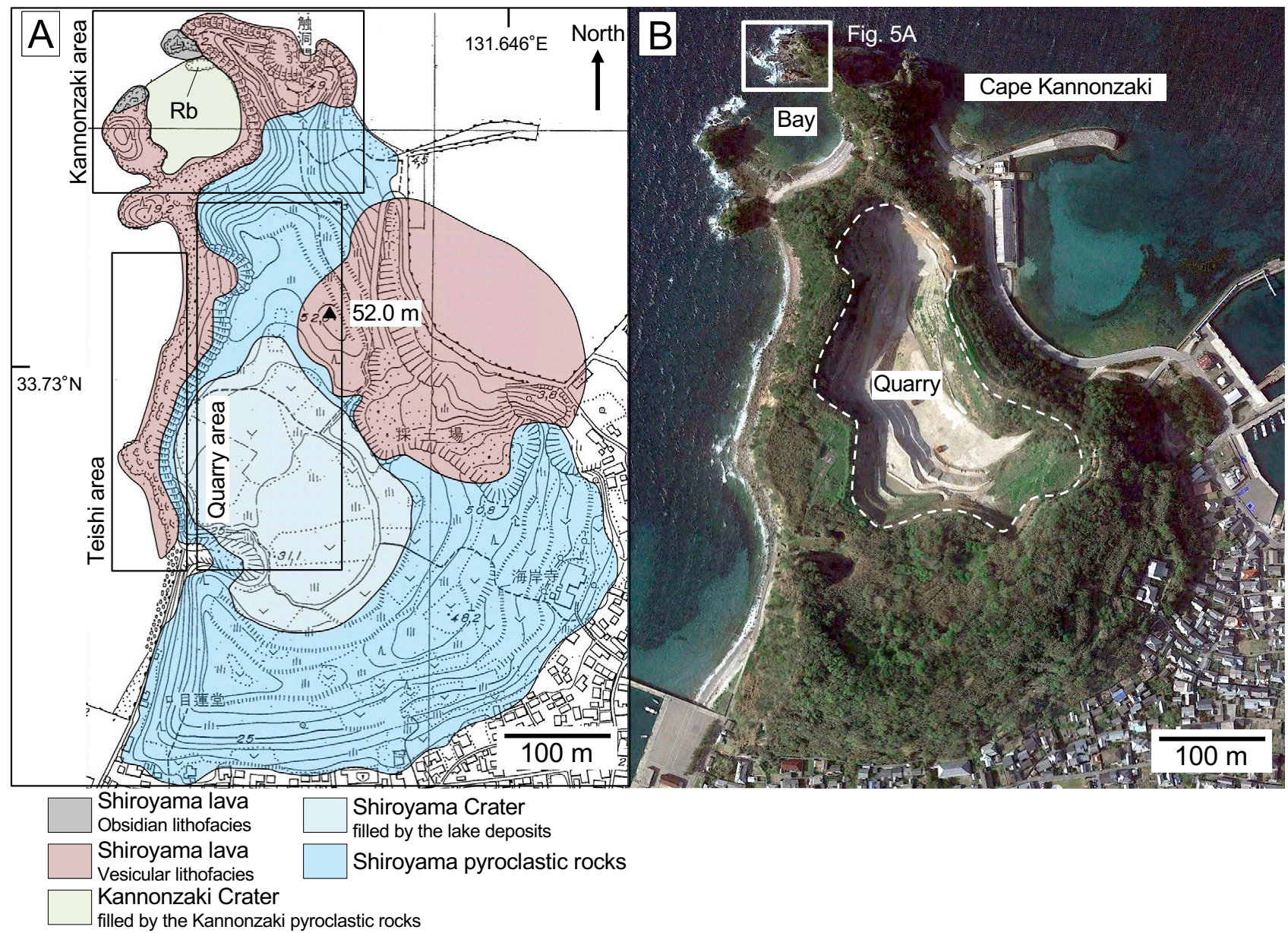

Figure 2: [A] Geological and topographic maps of the Shiroyama volcano. $\mathrm{Rb}$ is a rotated block of the Kannonzaki pyroclastic rocks. This map was modified from Itoh [1989] and a national large-scale map issued by the Geographical Survey Institute. The base map was created before the landform modification by quarrying. [B] Aerial view [GoogleEarth ${ }^{\mathrm{TM}}$ image] of the Shiroyama volcano. The dotted line shows area of the quarry.

ously identified. The length of Shiroyama lava is approximately $480 \mathrm{~m}$ from north to south. The bottom of the lava is not exposed, and the maximum thickness of the exposed part is $52 \mathrm{~m}$ [Itoh 1989]. The lava is broadly overlain by Shiroyama pyroclastic rocks (Figure 2A). The bulk chemical composition of the lava is 74-75 wt.\% $\mathrm{SiO}_{2}$ [Itoh 1990]. The lava contains garnet phenocrysts approximately $0.2 \mathrm{~mm}$ in size, and the matrix is composed of glass ( $>95 \mathrm{vol} . \%$ ) and groundmass of plagioclase and biotite [Itoh et al. 1997].

Itoh [1989] recognized the Kannonzaki and Shiroyama craters within the distribution area of Shiroyama lava (Figure $2 \mathrm{~A}$ ) and proposed that both craters were formed after the emplacement of Shiroyama lava. The activities of the Shiroyama crater commenced with the destruction of the pre-existing Shiroyama lava, and a pyroclastic cone composed of Shiroyama pyroclastic rocks were eventually formed on Shiroyama lava [Itoh 1989]. The Shiroyama crater was subsequently filled by lake deposits. Itoh [1989] also considered that the Kannonzaki crater was formed by the destruction of
Shiroyama lava. In contrast to the sequence proposed by Itoh [1989], our results showed that the effusion of Shiroyama lava was preceded by the activity of the Kannonzaki crater. The crater was eventually filled by the Kannonzaki pyroclastic rocks, which were supplied from the crater. The distribution of the Kannonzaki pyroclastic rocks is restricted within the crater, unlike that of the broadly scattered Shiroyama pyroclastic rocks (Figure 2A). Although a pyroclastic cone does not currently exist, Itoh [1989] considered that it had been formed on the crater.

\section{Geological Description}

Shiroyama lava is mainly divided into obsidian and vesicular lithofacies (Figure 2A). While most of the interior part of the lava is massive, the marginal part tends to be brecciated. We evaluated Shiroyama lava and the Kannonzaki pyroclastic rocks from three areas: the Kannonzaki, Quarry, and Teishi areas (Figure 2A). 

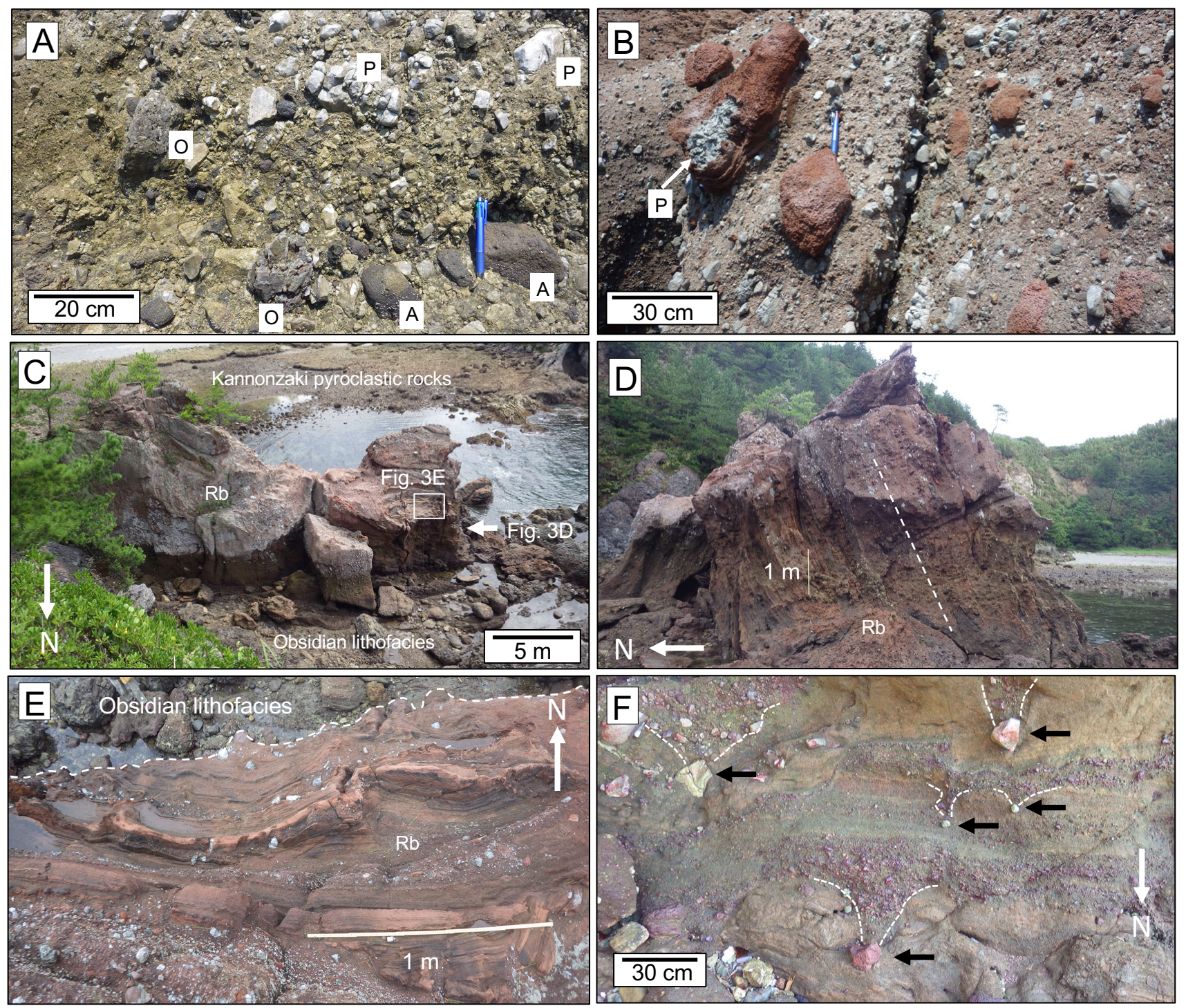

Figure 3: $[A]$ Tuff breccia of the Kannonzaki pyroclastic rocks. The clasts of obsidian lava (O), perlitic lava (P), and rounded andesite $(A)$ are included. $[B]$ The reddish pyroclastic rocks are also included as clasts. The clasts occasionally contain perlitic clasts. [C] Photograph (view to the south) showing the rotated block of the Kannonzaki pyroclastic rocks $(\mathrm{Rb})$ in the north margin of the bay. [D] Photograph (view to the east) showing the rotated block of the Kannonzaki pyroclastic rocks. The dotted line shows steep southward dipping of the bedding plane. [E] Upper surface of the block. The upper side of this photo shows the northern region, and the dotted line indicates boundary between the Kannonzaki pyroclastic rocks and obsidian lithofacies. The pyroclastic rocks are strongly deformed near the boundary. [F] The bomb sag structures (dotted lines and black arrows) developed in the block.

\subsection{Kannonzaki Area}

The Kannonzaki area is composed of Shiroyama lava and the Kannonzaki pyroclastic rocks. The obsidian lithofacies of Shiroyama lava is distributed in a narrow area of the tip of Cape Kannonzaki (Figure 2A). Distribution of the Kannonzaki pyroclastic rocks is restricted in the bay of Cape Kannonzaki. The shape of the Kannonzaki crater roughly follows the outline of the bay (Figure 2A and 2B).

\subsubsection{Kannonzaki pyroclastic rocks}

The Kannonzaki pyroclastic rocks are exclusively distributed in the bay, which is approximately $100 \mathrm{~m}$ in diameter [Itoh 1989] (Figure 2A). Most of the rock surfaces are usually below sea level, and they are accessible only at low tide. The Kannonzaki pyroclastic rocks are composed of alternate beds of tuff, lapilli tuff, and tuff breccia. Clasts of the pyroclastic rocks are composed of obsidian lava, perlitic lava, pyroclastic rocks including perlitic clasts, and rounded andesite (Figure $3 \mathrm{~A}$ and $3 \mathrm{~B}$ ). While the clasts of the obsidian and perlitic lavas and pyroclastic rocks are juvenile materials, rounded andesite clasts are reported to be derived 

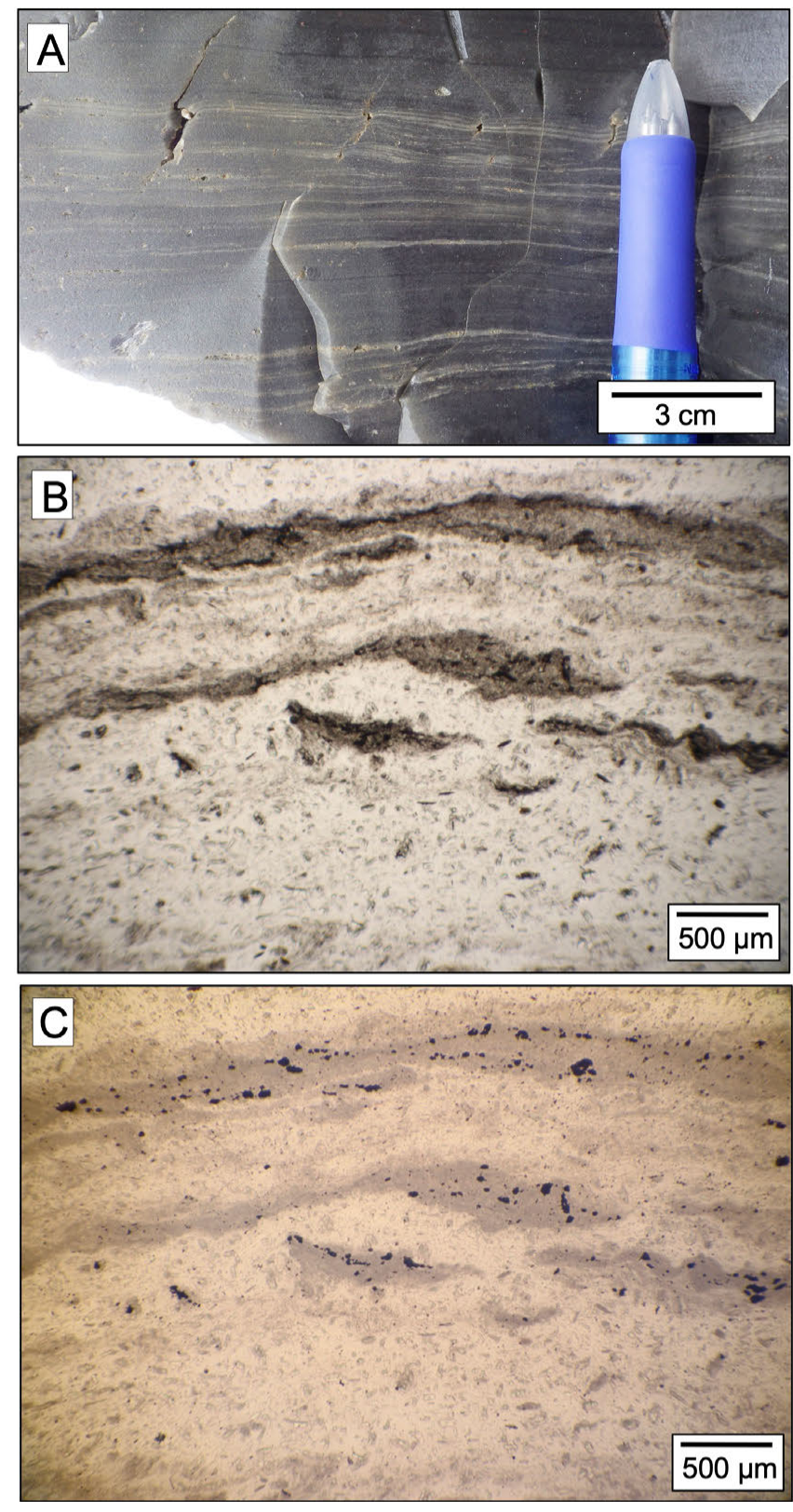

Figure 4: [A] Obsidian characterized by the welldeveloped flow banding defined by the difference in vesicularity. [B] Plane-polarized photomicrograph showing the flow banding. The black bands correspond to the light-colored bands in the outcrop. [C] Reflected light photomicrograph of $[\mathrm{B}]$. The black area indicates the cavity.

from the underlying Pleistocene sediments [Itoh 1989]. Strikes of the bedding planes of the pyroclastic rocks are concentrically arranged along the margin of the bay, and they dip $10-30^{\circ}$ toward the center of the bay [Itoh 1989]. Matrix ash often shows a reddish color. Based on the occurrences, Itoh interpreted that the bay is a crater filled by pyroclastic rocks.

There is a rotated block of the Kannonzaki pyroclastic rocks in the north margin of the bay, showing a bedding plane strike of $\mathrm{N} 80^{\circ} \mathrm{W}$ and $70-90^{\circ}$ southward dip- ping (Figure 3C and 3D). The block has an approximate width of $20 \mathrm{~m}$, length of $10 \mathrm{~m}$, and height of $5 \mathrm{~m}$. The pyroclastic rocks near contact with the obsidian lithofacies are strongly deformed by faults and folds (Figure $3 \mathrm{E}$ ). The bomb sag structures (Figure 3F) observed in the block show that the north side of the block was originally the base. Since the block was unlikely rotated over $90^{\circ}$ towards the north, it is reasonable to consider that the block was rotated $70-90^{\circ}$ towards the south.

\subsubsection{Obsidian lithofacies}

The obsidian lithofacies of Shiroyama lava are mainly distributed in the north and west sides of the Kannonzaki crater (Figure 2A). The obsidian lithofacies grade gradually into the vesicular lithofacies. The obsidian is characterized by well-developed flow banding defined by the difference in vesicularity (Figure $4 \mathrm{~A}$ ). In the outcrops, the part with high vesicularity shows a relatively light color (Figure 4B and 4C). The obsidian lithofacies are classified into three zones: brecciated obsidian, sheared brecciated obsidian, and massive to brecciated obsidian zones from south to north (Figure 5A). They are distributed roughly in the east-west strike direction.

The brecciated obsidian zone is distributed along the adjacent rotated block of the Kannonzaki pyroclastic rocks (Figure 5B and Figure 6A). Strike of the zone is slightly undulated, and the width is varied between mostly 20 and $80 \mathrm{~cm}$. The boundary with the rotated block of the Kannonzaki pyroclastic rocks is relatively sharp (Figure 6A). While most clasts are obsidian and chiefly $5-10 \mathrm{~cm}$ in diameter, the reddish clasts of the Kannonzaki pyroclastic rocks can be easily recognized (Figure 6B). The long axis of the clasts tends to be aligned in a nearly vertical orientation (Figure 6B). The matrix is mostly reddish in color.

The sheared brecciated obsidian zone, approximately $13 \mathrm{~m}$ in width, is distributed between the southern brecciated obsidian and northern massive to brecciated obsidian zones (Figure 5A and 5B). The obsidian lithofacies distributed west of the Kannonzaki crater is entirely composed of sheared brecciated obsidian. The clasts are entirely composed of obsidian and are vertically elongated and flattened, exhibiting a platy shape (Figure 7). The matrix is composed of fine-sized obsidian, and the obsidian particles exhibit ductile deformation, indicating comminution above the glass transition temperature [Ishikawa and Kamada 2009]. The matrix of the sheared brecciated obsidian near the side of the brecciated obsidian zone tends to show a red color (Figure 7). Foliation developed in the sheared brecciated obsidian zone due to the alignment of the platy obsidian clasts (Figure 5B). On the flattened surface of the platy obsidian clasts, parallel striations with a nearly vertical orientation are frequently recognized (Figure 8A). These observations indicate that the sheared brecciated obsidian records both of folia- 

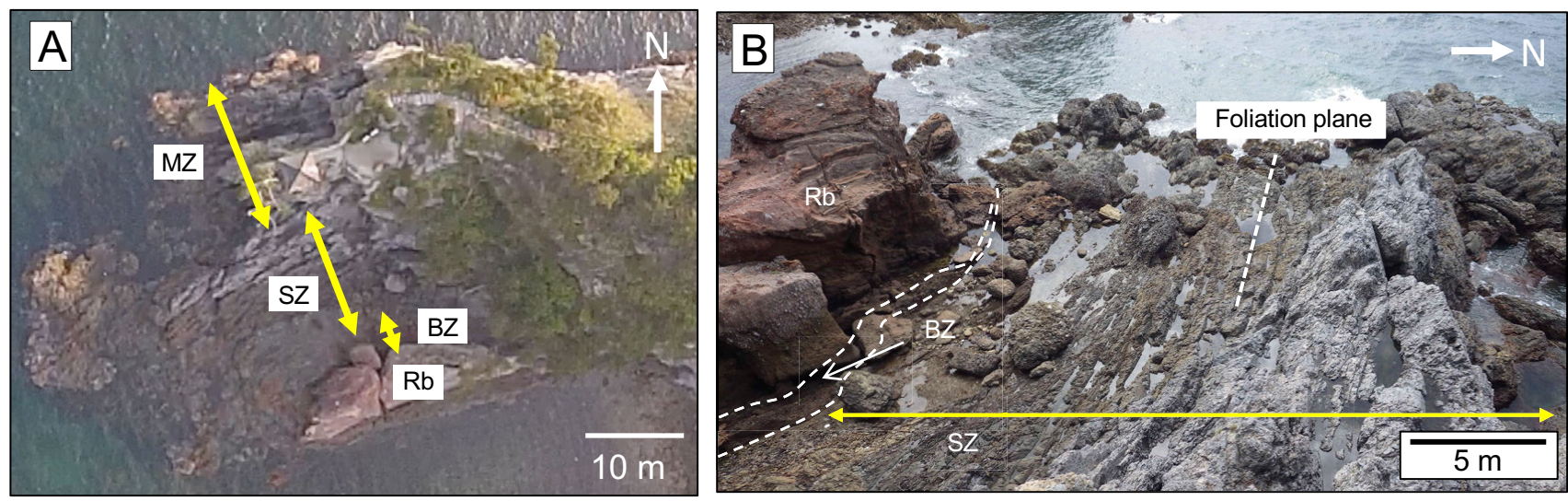

Figure 5: [A] Aerial drone image shows the zone classification of obsidian lithofacies; brecciated obsidian (BZ), sheared brecciated obsidian (SZ), and massive to brecciated obsidian (MZ) zones from south to north. The upper side of this photo shows the northern region. $\mathrm{Rb}$ - the rotated block of the Kannonzaki pyroclastic rocks. [B] Photograph (view to the west) showing the occurrences of the zones. The foliation planes (dotted line) are clearly developed in the sheared brecciated zone.


Figure 6: $[A]$ Boundary (dotted line) between the rotated block of the Kannonzaki pyroclastic rocks $(\mathrm{Rb})$ and the obsidian lithofacies. The view to the east. [B] Clasts of the reddish-colored Kannonzaki pyroclastic rocks (Kpr) are contained in the brecciated obsidian zone. The long axis of the clasts aligned nearly vertical orientation.

tion and lineation. Since the motion of obsidian may be recorded in the structure, we measured the attitudes of foliation and lineation using a compass clinometer from the sheared brecciated obsidian distributed north and west of the Kannonzaki crater (Figure 8B), obtaining 10 data points from both sides. The results show that both foliation and lineation indicate steep southward dipping. Furthermore, the attitudes are slightly different between both sides of obsidians. Lineations of the west and north obsidians dip to the east and west, respectively.

The massive to brecciated obsidian zone, approximately $22 \mathrm{~m}$ in width, occurred in the farthest area from the Kannonzaki pyroclastic rocks (Figure 5A). A large part of the zone is composed of massive obsidian (Figure 9A), while brecciated obsidian is partly recognized (Figure 9B). In the brecciated part, the clast alignment does not show a preferred orientation, unlike other obsidian zones. This zone characteristically contains rounded andesite clasts (Figure 9C). The oc- currences of the clasts resemble those of the andesite clasts in the Kannonzaki pyroclastic rocks. This indicates that the andesite clasts were derived from the underlying Pleistocene sediments. In the massive obsidian part, a patchy pumiceous structure is often developed (Figure 9D). Within the pumiceous parts, the interiors are more vesicular than the exteriors. Because the outlines of the pumices are always unclear, the pumiceous part appears to gradually change into obsidian. Although most of this zone is not fragmented, the fracture network is frequently developed (Figure 10A). The fractures are mostly $<5 \mathrm{~cm}$ in width. The fractures, called tuffisites, are filled with sintered or welded glassy fragments [Heap et al. 2019; Saubin et al. 2016; Tuffen and Dingwell 2004]. The observations indicate that fracturing occurred above the glass transition temperature [e.g. Tuffen and Dingwell 2004]. The black and light gray colors of the obsidian are recognized around the fracture network. The obsidian along the fracture is black, while the obsidian away from the fracture is light gray in color (Figure 10A). The difference 

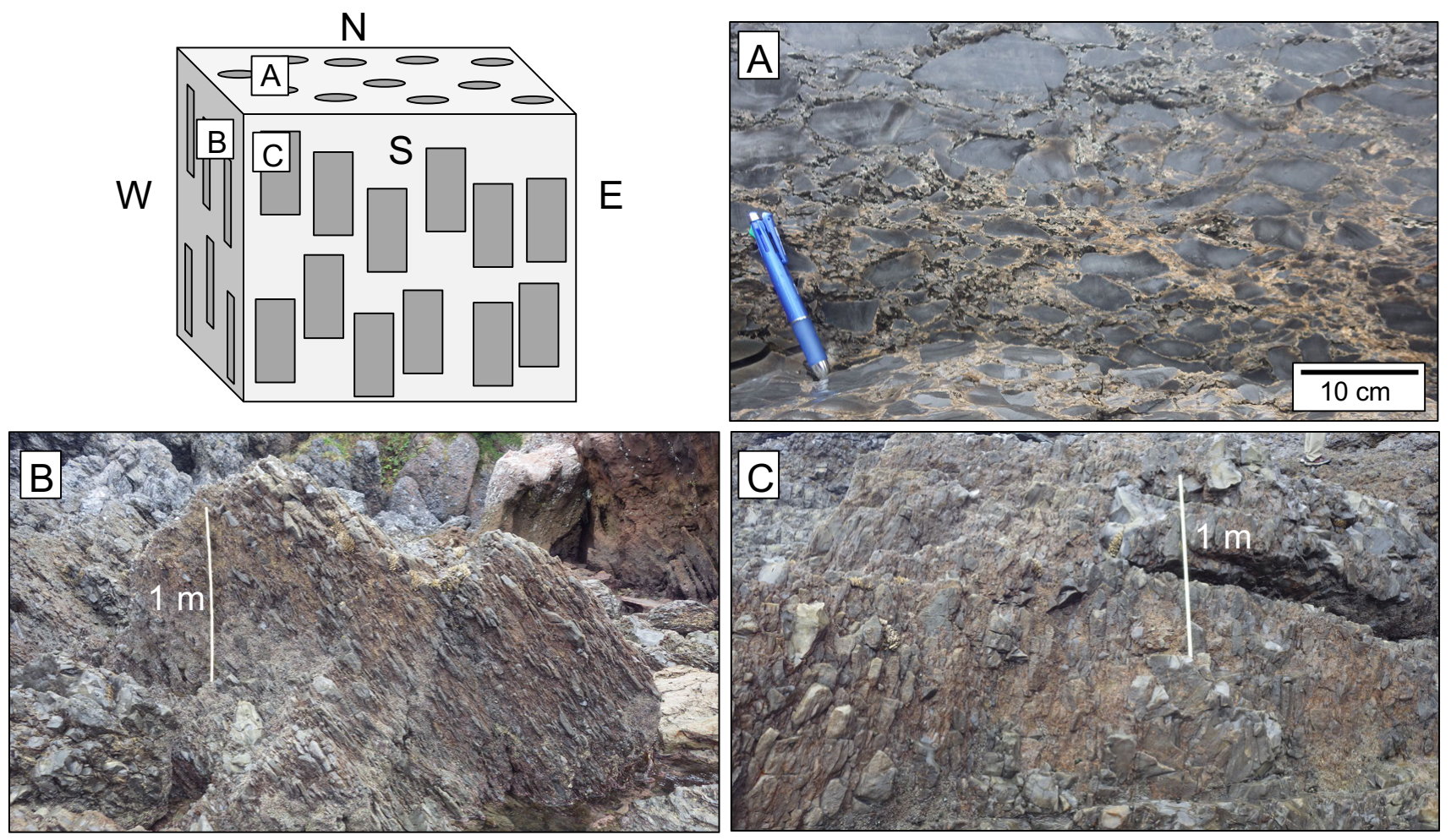

Figure 7: Schematic sections and photographs showing morphology of the obsidian clasts. Clasts are vertically elongated and flattened, exhibiting a platy shape. Matrix shows a red color.
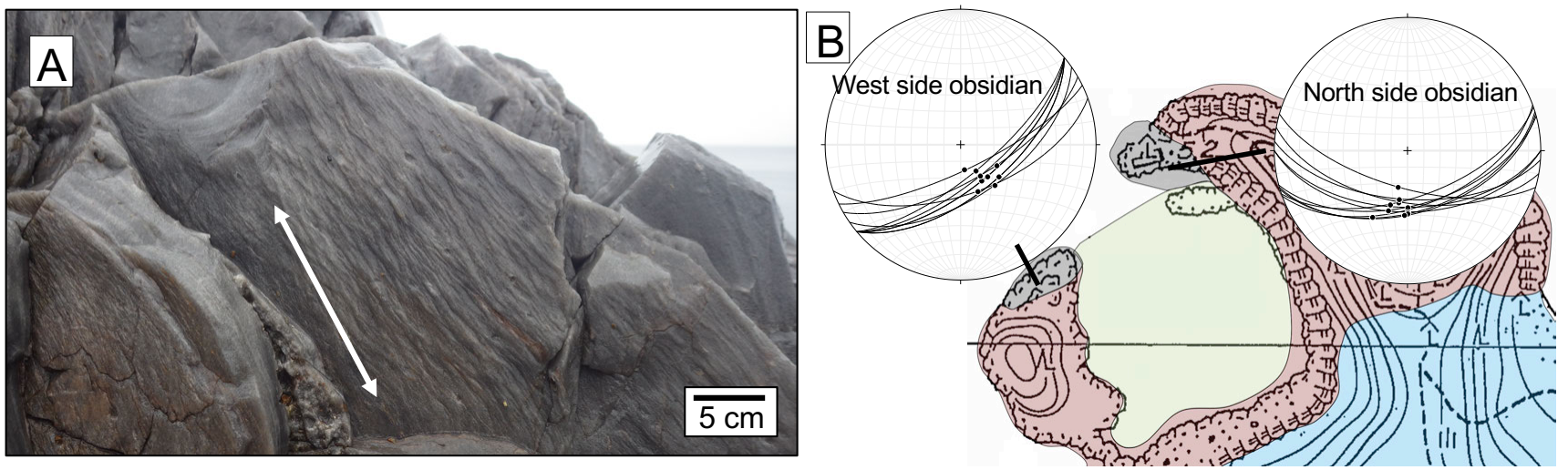

Figure 8: $[A]$ Nearly vertical parallel striations (double arrow) developed on the flattened surface of the platy obsidian clasts. [B] Foliation planes and striation rakes of the sheared obsidian clasts plotted on stereonets.

in the color attributes to the vesicularity; the bubblefree part is black. The fractures are often obscured and disappear, while the two-colored obsidian remains preserved (Figure 10B). In some cases, the two-colored obsidians are gradually flattened by ductile deformation, and flow banding is developed (Figure 10C). The pervasively developed flow banding of the obsidian is considered to have been formed by this process (Figure 4A).

\subsubsection{Vesicular lithofacies}

The vesicular lithofacies of the lava are gradually developed from obsidian lithofacies and override on the rotated block of the Kannonzaki pyroclastic rocks (Fig- ure 11A). The marginal part of the vesicular lithofacies is mostly brecciated. In the brecciated clasts, polyhedral and radial joints are frequently recognized (Figure 11B and 11C). Although the matrix is mainly composed of juvenile materials, reddish mud deposits, showing soft sediment deformation, occasionally occur in the matrix (Figure 11D). The mud deposits are interpreted as peperites. The polyhedral and radial joints of the clasts and peperites are interpreted to be developed by interaction with water and wet sediments [Cas and Wright 1987; Kano 1991; McLean et al. 2016; Yamagishi and Goto 1992].

In vesicular lithofacies around the Kannonzaki area, 

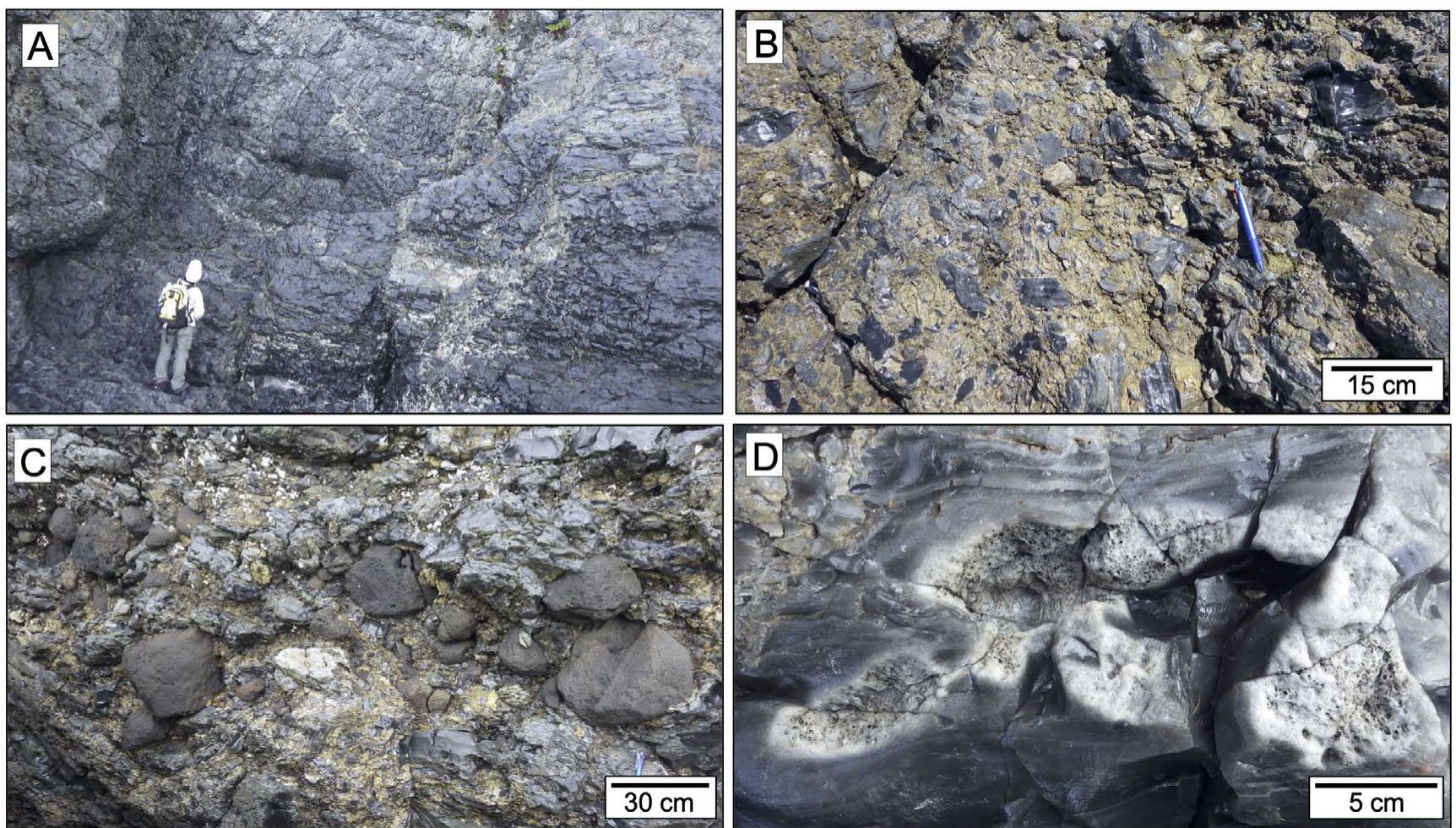

Figure 9: [A] Section showing the massive obsidian of the massive to brecciated obsidian zone. [B] Brecciated obsidian of the massive to brecciated obsidian zone. [C] Concentration of the rounded andesite clasts. [D] Patchy pumiceous structure developed in the massive obsidian.


Figure 10: [A] Fracture network developed in the massive obsidian. Note the obsidian along the fracture shows black color, while the obsidian away from the fracture shows light gray color. [B] Fracture network is obscured and disappear, while the two-colored obsidian remains preserved. [C] Flow bandings developed from the plastic deformation of the two-colored obsidians.

the perlite is widely developed, being generally $1-4 \mathrm{~cm}$ in diameter, resembling the macro perlite of Yamagishi and Goto [1992] (Figure 11E). Perlitic texture has been considered to result from the ingress of external water into fractures of a glassy lava [Denton et al. 2012; von
Aulock et al. 2013]. Clastic dikes, approximately $1 \mathrm{~m}$ in width, are also recognized in this area. The dikes are usually clast-supported and filled by mostly glassy lava clasts with perlitic texture (Figure 11F). The clasts of- 



Figure 11: $[A]$ Photograph showing the rotated block of the Kannonzaki pyroclastic rocks $(\mathrm{Rb})$ overridden by the vesicular lithofacies of Shiroyama lava. [B] Polyhedral joints developed in the brecciated vesicular lithofacies. [C] Radial joints (arrow) developed in the brecciated vesicular lithofacies. [D] Reddish mud deposits (dotted line) indicating peperites. [E] Perlitic texture resembling the macro perlite of Yamagishi and Goto [1992]. [F] Section showing a clastic dike. Dotted lines indicate the outlines. [G] Glassy clasts showing ductile deformation and adhesion each other (arrows).

ten show ductile deformation and adhere to each other, indicating entrainment above the glass transition temperature (Figure 11G). Itoh [1989] interpreted dikes as spiracles. Spiracles are inferred to have been created when flowing lava crossed wet sediments, and trapped water within the sediments is explosively converted to steam [Taniguchi 1982; Tolan et al. 2009]. The monolithologic lava clasts and adhered clasts of the clastic dike are consistent with the formation during lava flow.

In the bay of the Cape Kannonzaki, both the vesicular

lithofacies of Shiroyama lava and the Kannonzaki pyroclastic rocks are observed (Figure 12A). Their boundaries are highly deformed. The Kannonzaki pyroclastic rocks are deformed along the lava margin (Figure 12B) and occasionally infiltrate into the interspace of the lava. The Kannonzaki pyroclastic rocks along the lava margin often show a reddish color (Figure 12C), and the infiltrated pyroclastic rocks tend to show darker red (Figure 12D). 

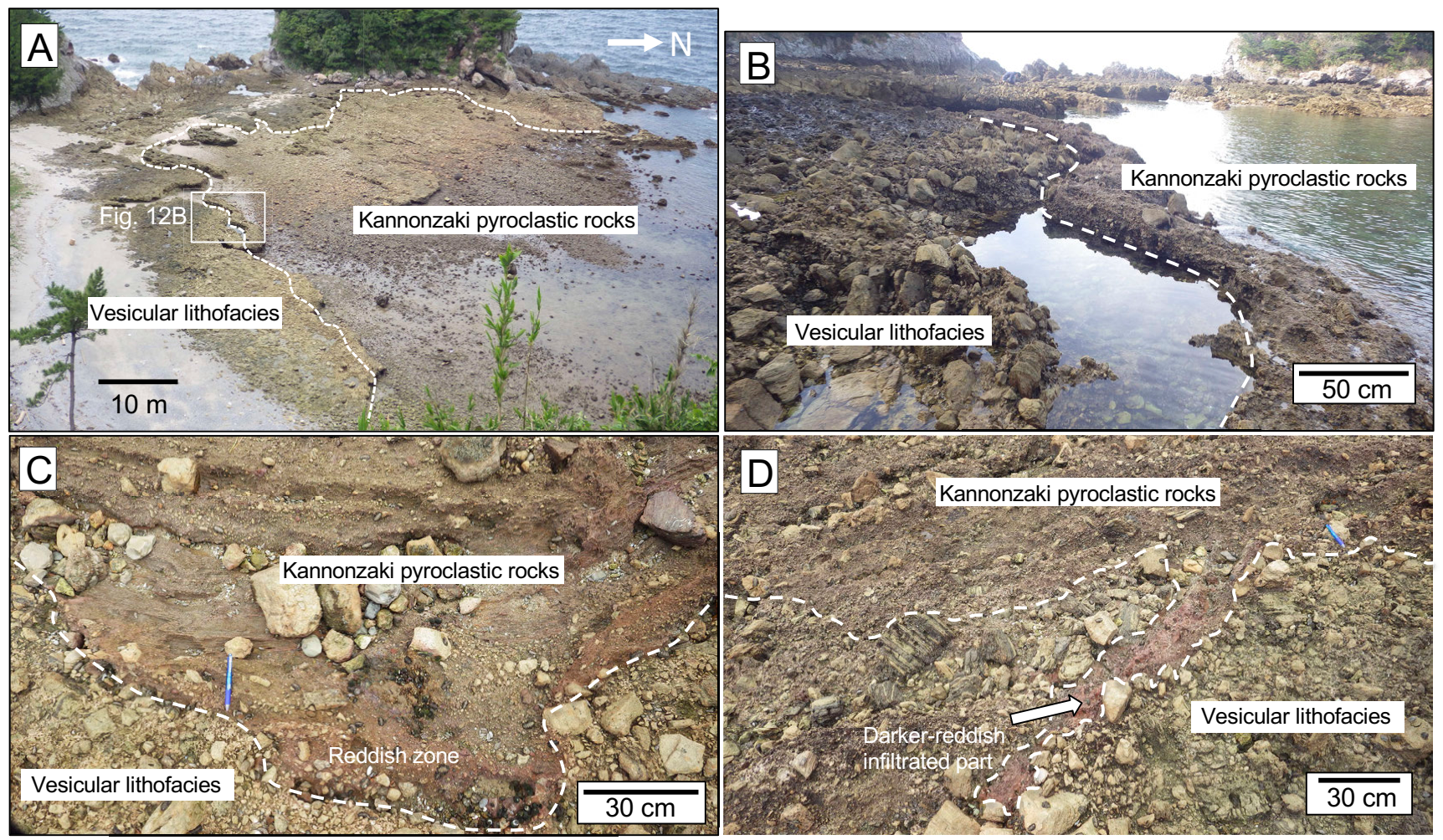

Figure 12: $[\mathrm{A}]$ Photograph (view to the west) indicating boundary (dotted line) of the vesicular lithofacies of Shiroyama lava and the Kannonzaki pyroclastic rocks. [B] Close-up view of the contact (dotted line) of them. The Kannonzaki pyroclastic rocks are deformed along the lava margin. [C] The Kannonzaki pyroclastic rocks along the lava margin (dotted line) show reddish color, indicating oxidized. [D] The infiltrated part (arrow) of the Kannonzaki pyroclastic rocks show darker reddish color.

\subsection{Quarry area}

A quarry is established in the inner area of the lava (Figure 2B) and exposes a north-south section of the lava. Massive vesicular lithofacies are entirely distributed in the quarry. The maximum thickness of the quarry is approximately $45 \mathrm{~m}$. Obsidian blocks, mostly $<10 \mathrm{~cm}$ in diameter, are often recognized from there. They would have been derived from the obsidian lithofacies of the Kannonzaki area as entrained clasts and/or ballistic ejecta. Although the structural development of massive obsidian layers below a surficial pumiceous layer has been reported from rhyolite lavas [Furukawa et al. 2019; Furukawa et al. 2010; Manley and Fink 1987], obsidian layers have not been recognized in Shiroyama lava. Perlitic texture, spiracles, and polyhedral and radial fractures, which imply interaction with water, were not identified from the quarry area, unlike the Kannonzaki area. Flow banding was extensively developed (Figure 13A). The black color band is defined by a low vesicularity part similar to that of obsidian. The lava margin, covered by the Shiroyama pyroclastic rocks, is exposed in the southern part of the quarry. The lava margin is characterized by a layering structure formed by the platy joints (Figure 13B). The joints show buckle folding with a wavelength of 1-
$2 \mathrm{~m}$ (Figure 13B). Buckle folds are common in rhyolite lavas [Castro and Cashman 1999] and formed via layerparallel compression. This lava margin is partly brecciated, and en echelon cracks, indicating shear stress, are frequently recognized within the platy joints (Figure 13C). These occurrences show that the compressive and shear stresses continued after emplacement and likely resulted from the pressure from the inner moving lava.

Vesicularity varies in the quarry and tends to be higher on the north side. We impregnated thin sections with yellow resin to observe the detailed bubble morphology. In the northernmost part of the quarry, the vesicularity, which is estimated from the area ratios of the photomicrographs, of the lava is $70-80 \%$. The shape of the bubbles is relatively spherical (Figure 13D). Structures indicating bubble coalescence, such as bending and dimpling [Castro et al. 2012b; Martel and Iacono-Marziano 2015], were observed. In the central part of the quarry, the vesicularity of the lava is $45-60 \%$. The bubbles are highly flattened, indicating significant flow-induced shear (Figure 13E). The streak texture resulting from bubble collapse is frequently observed (Figure 13F). The texture of the southern margin of the lava resembles that of the Teishi area, as described in the following section. 



Figure 13: [A] Vesicular lithofacies of Shiroyama lava in the quarry. Flow banding is conspicuous. [B] Platy joints and their buckle folding in the lava margin. [C] En echelon cracks developed in the lava margin. [D] Plane-polarized photomicrograph showing the bubbles (yellow area) of the vesicular lithofacies in the northernmost part of the quarry. Note their spherical shape and interconnection. [E] Plane-polarized photomicrograph showing the bubbles of the vesicular lithofacies in the central part of the quarry. [F] Bubbles are highly elongated and collapsed.

\subsection{Teishi area}

In the Teishi area, an entirely brecciated lava margin of the vesicular lithofacies is exposed. The lava is directly covered by the Shiroyama pyroclastic rocks. Perlitic texture, spiracles, and polyhedral and radial fractures were not recognized from the Teishi area. Dense flow bands are usually developed in the lava (Figure 14A). The black band in the hand sample is clear under a microscope (Figure 14B), is defined by the low vesicularity part similar to those of the obsidian and vesicular litho- facies of the quarry (Figure 14A and Figure 13A). The vesicularity of the lava is $15-25 \%$, which is measurably lower than those of the vesicular lithofacies in other areas.

\section{Methods}

\subsection{Magnetic susceptibility measurement}

In the brecciated obsidian zone distributed in the southern margin of the obsidian lithofacies, clasts from 

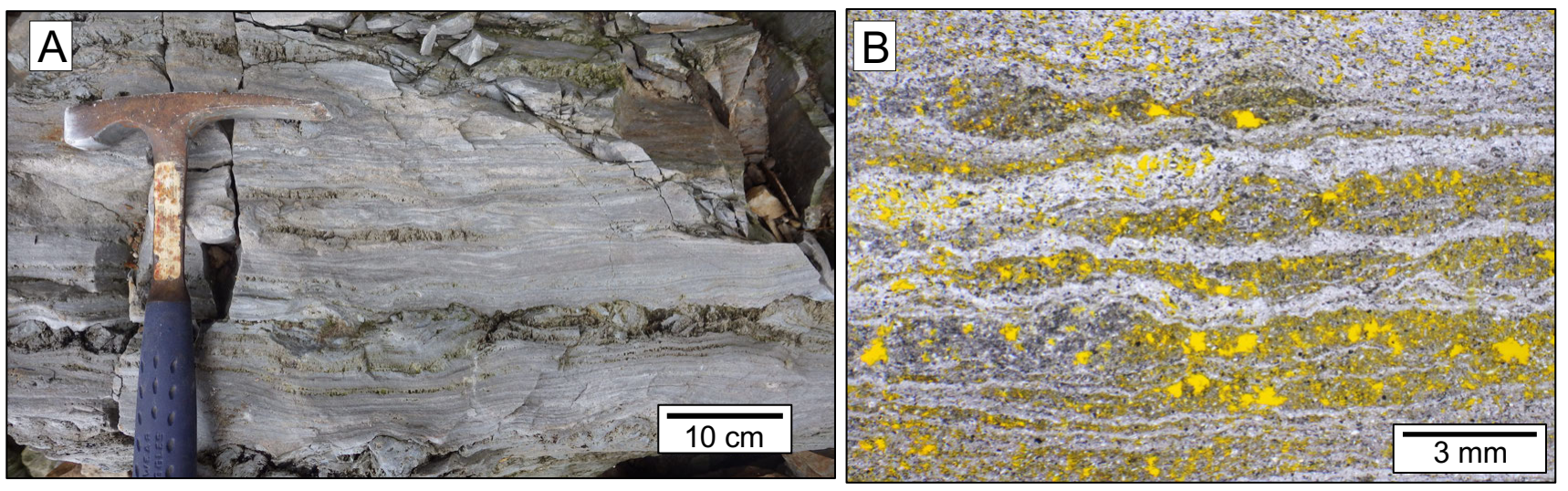

Figure 14: $[\mathrm{A}]$ Photograph showing the vesicular lithofacies of Shiroyama lava in the Teishi area. Dense flow bands are developed. [B] Plane-polarized photomicrograph showing the flow bands. Black bands of this photomicrograph correspond to the light-colored bands in the outcrop.

the adjacent Kannonzaki pyroclastic rocks are incorporated. We measured the magnetic susceptibility to confirm the mixing of the Kannonzaki pyroclastic rocks into obsidian lithofacies.

Magnetic susceptibility was determined in the field using a Tanaka geological corporation WSL-C portable magnetic susceptibility meter and investigated at three sites: matrices of the sheared brecciated obsidian, brecciated obsidian zones, and adjacent Kannonzaki pyroclastic rocks. Measurements were taken 15-20 times at each site. The error in the measurements is less than $2 \%$.

\subsection{Anisotropy of magnetic susceptibility (AMS) mea- surement}

The AMS of a lava sample reflects the alignment of magnetic minerals and can record the flow direction and internal strain of a lava and pyroclastic flow deposit [e.g. Cañón-Tapia and Mendoza-Borunda 2014; Furukawa and Uno 2015; Shields et al. 2016]. Therefore, AMS has contributed to research in the field of volcanology. In this study, AMS measurements were conducted to reveal the detailed deformation history of Shiroyama lava.

The AMS samples were collected from 5 sites (sites 2, 5, 6, 8, and 9; Figure 15A). All samples were hand samples. The samples were oriented in the field using a tripod-mounted magnetic compass. The specimens were drilled in the laboratory, yielding cores $25 \mathrm{~mm}$ in diameter and $22 \mathrm{~mm}$ in length. In total, 11-36 oriented specimens were analyzed from each sampling site.

We measured the AMS of the samples using a susceptibility bridge (KLY-3, AGICO, Inc.) at Okayama University to evaluate the bulk magnetic fabric. AMS can be represented by an ellipsoid with three principal axes denoted as $k_{\max }>k_{\text {int }}>k_{\min }$. The results were projected onto an equal-area projection and analyzed using Jelínek statistics. The shape parameter $T$ and the degree of anisotropy $P$ were calculated using Jelínek's method.

\subsection{Density measurement}

The apparent densities of the obsidian and vesicular samples were measured using the glass-beads method [Sasaki and Katsui 1981]. We can analyze the apparent densities easily, quickly, and non-destructive by the method. Measurements were taken from 9 sites, with 3-16 samples each (Figure 15A). Site 1 is the obsidian, and sites 2-9 are the vesicular lithofacies. Obsidian samples were collected from the quarry. Because obsidian is considered to be derived from obsidian lithofacies in the Kannonzaki area, we selected this area as a sampling site (site 1). All samples were washed with water and dried at $60{ }^{\circ} \mathrm{C}$ for three days. Each sample was placed in a graduated cylinder filled with glass beads. The using glass beads are $0.8 \mathrm{~mm}$ in diameter, which is slightly larger than that of vesicles. In a size lower than that, glass beads infill the vesicles, and the results will be inaccurate. The increased volume corresponded to the bulk volume of the sample. The apparent density of each sample was estimated from its volume and weight.

\subsection{Water concentration measurement}

Water concentrations were estimated from obsidian (site 1; Figure 15A) and vesicular lithofacies (sites 2, 6, and 9; Figure 15A) samples to help elucidate the degassing process. In the obsidian sample, a black streak cut across the sample was recognized (Figure 16A). The black streak is composed of a bubble-free part probably developed along the healed fracture as well as the occurrence of Figure 10B. We measured the water concentration from both the massive and the black healedfracture parts of the obsidian sample.

The water content was measured by Fourier transform infrared (FTIR) spectroscopy. The analyses were 




Figure 15: [A] Map indicates the sampling sites for density measurements (sites 1-9), FTIR analyses (sites 1, 2, 6, and 9 ), and anisotropy of magnetic susceptibility measurements (sites 2, 5, 6, 8, and 9). [B] Results of the density measurements. The vesicularity is also attached. [C] Results of the FTIR analyses.
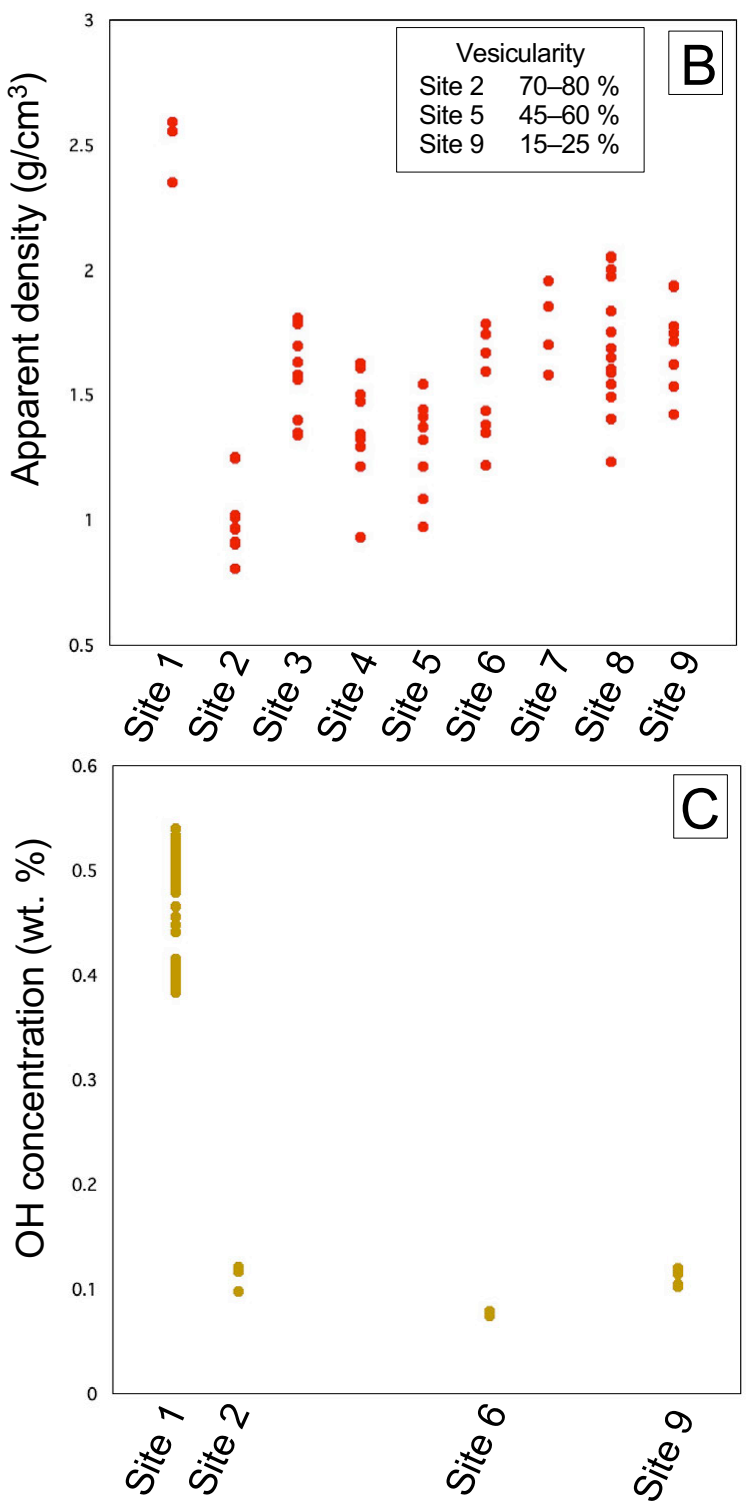

conducted at Kwansei Gakuin University using a Shimadzu IRPrestige-21 spectrometer with an AIM-8800 infrared microscope. Infrared spectra were collected using a Ge-coated $\mathrm{KBr}$ beamsplitter. The results were obtained over a wavelength range of $4000-400 \mathrm{~cm}^{-1}$, with a liquid-nitrogen cooled MCT detector and an aperture set at $15 \mu \mathrm{m}$ square. Samples were prepared as doubly polished wafers with a thickness of $43-150 \mu \mathrm{m}$.

The concentration of total dissolved water $\left(\mathrm{H}_{2} \mathrm{O}_{t}\right)$ and water dissolved as molecular water $\left(\mathrm{H}_{2} \mathrm{O}_{\mathrm{m}}\right)$ was determined from the absorbance bands at 3550 and $1630 \mathrm{~cm}^{-1}$, respectively [Wysoczanski and Tani 2006] using the Beer-Lambert law:

$$
\text { wt. } \%=100 \frac{M A}{\rho d \varepsilon}
$$

where $M$ is the molecular weight $\left(18.02 \mathrm{~g} \mathrm{~mol}^{-1}\right.$ for water), $A$ is the height of the spectral band of interest, $\rho$ is the density $\left(\mathrm{g} \mathrm{L}^{-1}\right), d$ is the sample thickness $(\mathrm{cm})$, and $\varepsilon$ is the molar absorptivity coefficient for the ab- sorbance band of interest $\left(\mathrm{L} \mathrm{mol}^{-1} \mathrm{~cm}^{-1}\right)$. Absorbance peak heights were determined using a straight baseline. The glass density was $2350 \mathrm{~g} \mathrm{~L}^{-1} \cdot \mathrm{H}_{2} \mathrm{O}_{\mathrm{t}}$ was calculated from the peak at $3550 \mathrm{~cm}^{-1}$ and $\mathrm{H}_{2} \mathrm{O}_{\mathrm{m}}$ from the peak at $1630 \mathrm{~cm}^{-1}$, using respective molar absorptivity coefficients of 90 and 55 [McIntosh et al. 2014]. Since $\mathrm{H}_{2} \mathrm{O}_{t}$ is the sum of $\mathrm{H}_{2} \mathrm{Om}$ and $\mathrm{OH}, \mathrm{OH}$ can be quantified by the above process.

The two species $\left(\mathrm{H}_{2} \mathrm{O}_{\mathrm{m}}\right.$ and $\left.\mathrm{OH}\right)$ are interconverted in silicate melts and glasses [McIntosh et al. 2017]. The reaction rate is strongly controlled by temperature and slows dramatically with cooling [Zhang et al. 1995]. Since species interconversion is negligible at low temperatures, water is added at ambient temperature by rehydration as $\mathrm{H}_{2} \mathrm{O}_{\mathrm{m}}$ and not interconverted to $\mathrm{OH}$ [McIntosh et al. 2017]. Thus, rehydration increases both $\mathrm{H}_{2} \mathrm{O}_{\mathrm{t}}$ and $\mathrm{H}_{2} \mathrm{O}_{\mathrm{m}} / \mathrm{OH}$ ratios [Mitchell et al. 2018]. Giachetti et al. [2015] suggested that samples with high connected porosity and ages of approximately 1000 years may contain a significant amount of 



Figure 16: [A] Obsidian sample with the healed fracture for FTIR analyses. [B] Results of the FTIR analyses of the massive and healed fracture parts.

water. Because Shiroyama lava meets these conditions, it may have been subject to rehydration. Therefore, a comparison of $\mathrm{H}_{2} \mathrm{O}_{\mathrm{t}}$ or $\mathrm{H}_{2} \mathrm{O}_{\mathrm{m}}$ to discuss the degassing process may not be suitable. The $\mathrm{H}_{2} \mathrm{O}_{\mathrm{m}} / \mathrm{OH}$ ratio varies with magma ascent velocity (cooling rate) [Castro et al. 2012a]. Because all samples were collected from the same lava, the $\mathrm{H}_{2} \mathrm{O}_{m} / \mathrm{OH}$ ratios were expected to be initially equal. Therefore, we compared $\mathrm{OH}$ concentration to discuss the qualitative degassing process because it is not controlled by the rehydration process, unlike $\mathrm{H}_{2} \mathrm{O}_{\mathrm{m}}$ concentration.

\section{Results}

\subsection{Magnetic susceptibility measurement}

The results of magnetic susceptibility varied between $1.9 \times 10^{-5}$ and $99.5 \times 10^{-5}$ SI (Figure 17). The values of the sheared brecciated obsidian, brecciated obsidian zones, and adjacent Kannonzaki pyroclastic rocks were $3.1 \pm 0.7 \times 10^{-5}$ SI, $17.2 \pm 7.4 \times 10^{-5}$ SI, and $71.5 \pm$ $14.8 \times 10^{-5}$ SI, respectively. The values of each lithology were statistically different from each other within error limit, and it was possible to distinguish them from each other by the magnetic susceptibility value. The magnetic susceptibility of the brecciated obsidian zone shows intermediate values. The results of magnetic susceptibility together with geological observation indicate that the Kannonzaki pyroclastic rocks are somewhat entrained into the obsidian lithofacies at the matrix and clast scales.

4.2 Anisotropy of magnetic susceptibility (AMS) measurement

The results of the AMS measurement are shown in Table A1. The $T$ and $P$ of Jelínek varied between -0.955 (8) Presses universitaires de strasbourg and 1.150 and between 1.012 and 1.299 , respectively. The two groups were recognized based on the $T-P$ diagram (Figure 18A). For the group composed of sites 2,8 , and 9 , the $T$ value indicates that the shapes of AMS ellipsoids are broadly distributed between oblate and prolate. For the group composed of sites 5 and 6 , the $T$ value suggests that the shapes of AMS ellipsoids are conspicuously oblate, and the $P^{\prime}$ value is distinctly higher than that of the other groups. The higher $P^{\prime}$ values in the samples with highly elongated bubbles are

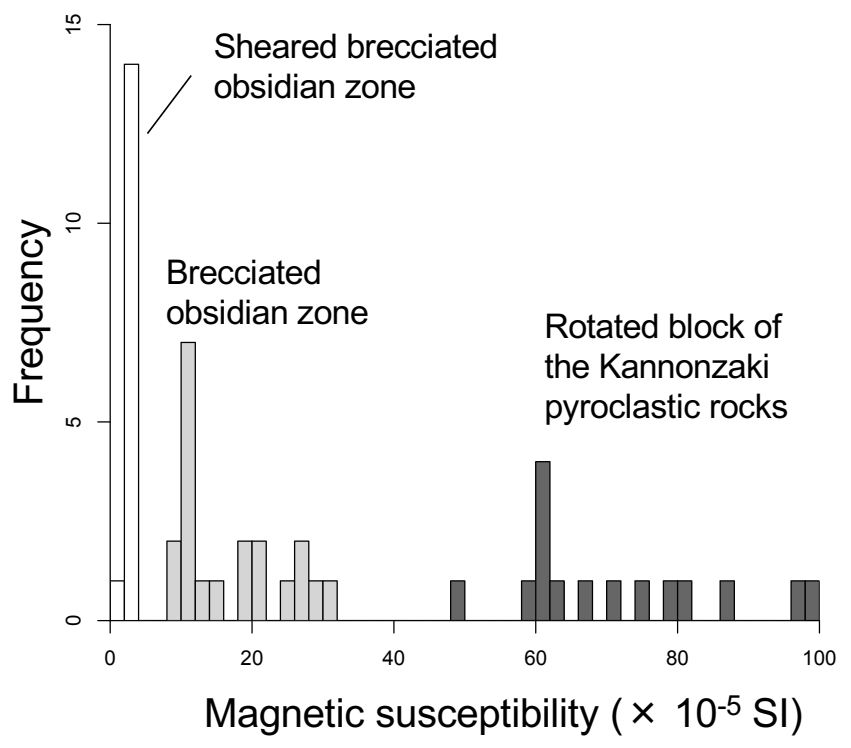

Figure 17: Results of the magnetic susceptibility of the matrices of the sheared brecciated obsidian, brecciated obsidian zones, and the adjacent Kannonzaki pyroclastic rocks. 
consistent with the results obtained by Shields et al. [2016].

The orientation of the principal susceptibility axes of all specimens is shown in Figure 18B-F. The group composed of sites 2, 8, and 9 indicate that the principal susceptibility axes have a broad distribution (Figure $18 \mathrm{~B}, \mathrm{E}$, and $\mathrm{F}$ ). At these sites, the confidence limits of the axes intersect. These characteristics of the principal susceptibility axes are likely relevant to the low degree of anisotropy (low $P^{\prime}$ value). Conversely, the principal susceptibility axes of a group of sites 5 and 6 tend to be clustered (Figure 18C and D). The plane defined by the $k_{\max }-k_{\text {int }}$ axes dips eastward, and the $k_{\max }$ axis indicates the EW direction. The flow-foliation planes of sites 5 and 6 can be recognized, although it is difficult to measure the attitude of the flow-foliation planes of sites 2, 8, and 9 owing to their obscureness and complicated folding. The foliation planes of sites 5 and 6 are also shown in Figure $18 \mathrm{C}$ and D. The results show that the plane defined by the $k_{\max }-k_{\text {int }}$ axes (the AMS foliation plane) coincides with their flow-foliation planes.

\subsection{Density measurement}

The apparent density results varied between 0.80 and $2.59 \mathrm{~g} \mathrm{~cm}^{-3}$ (Figure 15B). The obsidian samples (site 1) showed a higher apparent density relative to those of the vesicular lithofacies samples (sites 2-9). The apparent density of site 2, which is in the northernmost part of the quarry, was lowest, as can be expected from samples with the highest vesicularity. The results of sites 2-9 indicate that apparent density gradually increases toward the south.

\subsection{Water concentration measurement}

The results are shown in Table A2 and Figure 15C. The total $\mathrm{H}_{2} \mathrm{O}$ concentration of obsidian was approximately 0.8 wt. $\%$, which is slightly higher than that of typical of obsidian lava [0.1-0.4 wt.\% Shields et al. 2016]. The $\mathrm{OH}$ concentrations of obsidian (site 1) and vesicular lithofacies (sites 2, 6, and 9) samples varied between 0.38 and 0.54 wt. $\%$ and between 0.07 and 0.12 wt. $\%$, respectively. In the vesicular lithofacies of the three sites, $\mathrm{OH}$ concentrations were nearly constant. The discrepancy of the $\mathrm{OH}$ concentrations between the obsidian and vesicular lithofacies of $0.3-0.4 \mathrm{wt} . \%$ indicates the removal of volatiles from the lava. This result shows that obsidian lithofacies develop into vesicular lithofacies with degassing. In the obsidian sample, the $\mathrm{OH}$ concentration of the healed-fracture part tended to be broad and $<0.16 \mathrm{wt} \%$ lower than that of the massive part (Figure 16B).

\section{Discussion}

\subsection{Source of Shiroyama lava}

Shiroyama lava is roughly enclosed by brecciated lithofacies, while the inner part of the lava is massive. Because brecciated lithofacies are usually developed in the flow margin, the original distribution of Shiroyama lava is considered to have not been modified by significant erosion.

The distribution of obsidian lithofacies is restricted to a narrow area of the tip of Cape Kannonzaki (Figure 2A), while the vesicular lithofacies comprises a large part of the lava. Rhyolite lavas are usually effused as dense obsidian and vesiculate as they flow away from the vent [Castro et al. 2005; Fink et al. 1992; Furukawa et al. 2019; Ramsey and Fink 1999]. We showed that the sheared brecciated obsidian records both of foliation and lineation indicating steep southward dipping (Figure 8B). Since the attitudes reflect the motion of the lithofacies, the obsidian is considered to have been transported nearly vertically from below the Kannonzaki crater. Thus, the obsidian lithofacies of the Kannonzaki area were determined to be the source of Shiroyama lava. The lava spreads southward with vesiculation. The subsequent vesiculation is consistent with the results of density measurements and FTIR analyses. The spreading resulted in a fan-shaped flow field. The fan-shaped spreading is a usual method for rhyolite lavas, such as the Big Glass Mountains in California [Fink 1980], Takanoobane rhyolite lava in Japan [Furukawa and Uno 2015], and the obsidian flow of the Cordón Caulle volcano in Chile [Tuffen et al. 2013].

\subsection{Emplacement environment of Shiroyama lava}

Shiroyama lava involves structures indicating interaction with water and wet sediments such as polyhedral and radial joints, peperite, perlitic texture, and spiracles. Specifically, spiracles demonstrate that only the base of the lava was soaked in water and in contact with wet sediment [Taniguchi 1982]. The Kannonzaki pyroclastic rocks exhibit a reddish matrix, indicating hightemperature oxidation in a subaerial environment. This reveals that the lava was effused at sea with shallow water, likely at a water depth of under several meters. However, the lack of structures indicating interaction with water, except for the Kannonzaki area, means that the wet environment was restricted in the source area. From this, it can be concluded that the lava was effused around the coastline and flowed southward on the land surface.

\subsection{Emplacement process of the obsidian lithofacies}

We demonstrated that obsidian lithofacies developed in the source area, which is the tip of Cape Kannonzaki. The obsidian lithofacies were classified into brecciated, sheared brecciated, and massive to brecciated zones from south to north (Figure 5). The degree of Pbreckint 

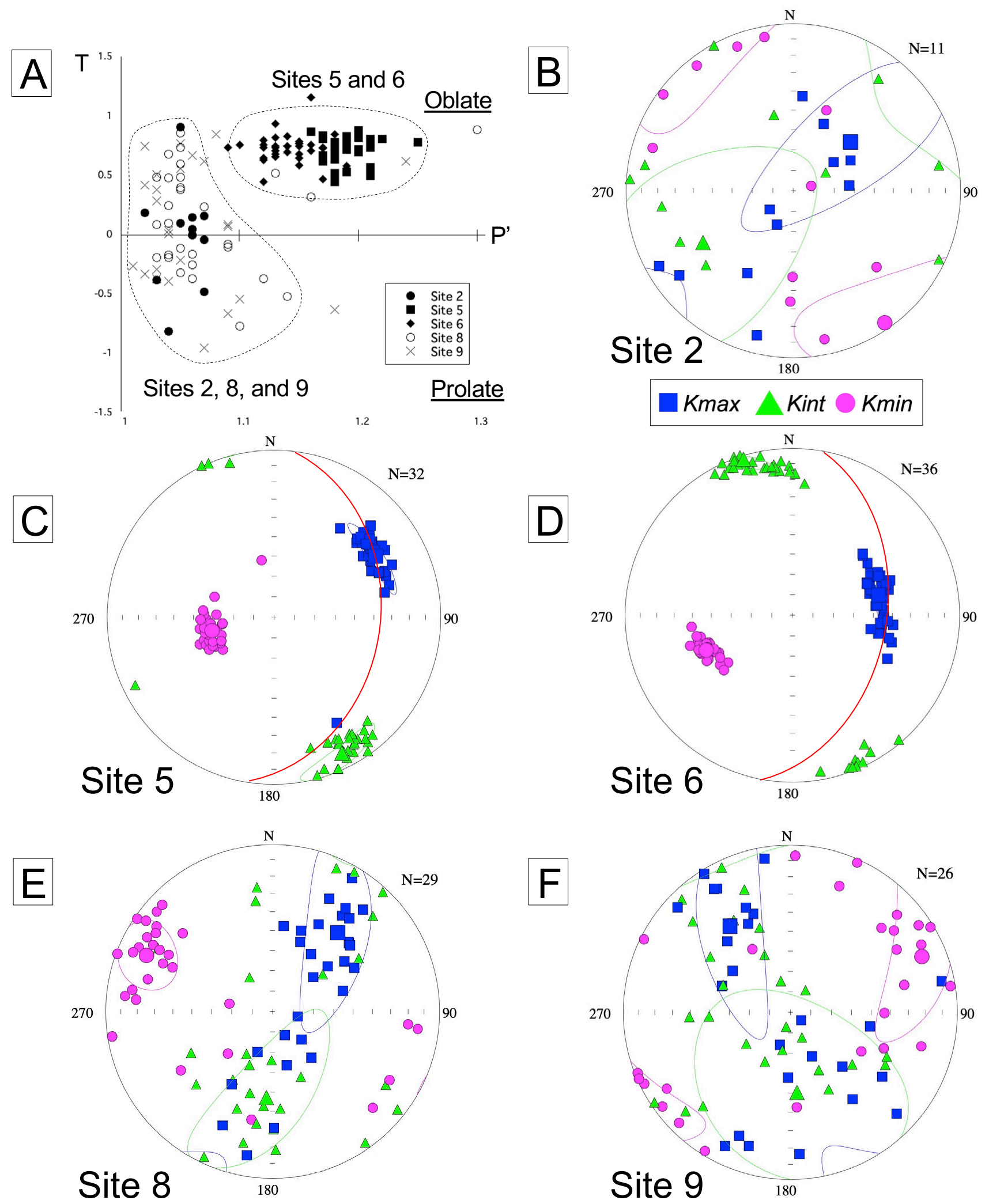

Figure 18: [A] Plot of the AMS shape parameter $(T)$ against the degree of anisotropy $\left(P^{\prime}\right)$ of the five sites. [B-F] Orientation of the principal susceptibility axes of all the specimens. Solid squares, triangles, and circles represent the maximum, intermediate, and minimum axes, respectively. Great circle in sites 5 and 6 shows the foliation planes developed in the lava. 
tion tends to increase toward the south, and the south margin is in contact with the rotated block of the outer Kannonzaki pyroclastic rocks, at which the outer Kannonzaki pyroclastic rocks are intermingled in the brecciated zone. In the brecciated and sheared brecciated obsidian zones, the vertical foliation and lineation are conspicuous.

We consider that the obsidian lithofacies in this study correspond to the shallow conduit. The silicic conduit structures have been presented via investigation of spines and dissected conduits. The horizontal sections are well investigated in Mount St. Helens [Gaunt et al. 2014; Pallister et al. 2012] and Chaos Crags [Ryan et al. 2020], USA. The studies show that the silicic conduit structures are composed of the fault gouge zone, cataclastic and sheared zone, and massive zone from outer edge to the center. The marginal fault zone has also been reported from spines of the 1991 to 1995 eruption of Unzen volcano [Hornby et al. 2015; Lamb et al. 2015; Nakada et al. 1999] and the 1996 eruption of Soufrière Hills [Sparks et al. 2000]. Since the conduit margin is damaged due to strain localization during magma ascent [Gaunt et al. 2014], the degree of brecciation tends to increase toward the conduit margin. The horizontal structural variation is very similar to that of the obsidian lithofacies of Shiroyama lava, and the brecciated lithofacies in southern part should be the conduit margin. Parallel striations with nearly vertical orientation are interpreted as slickensides formed by faulting during magma ascent such as Pallister et al. [2012], Simões et al. [2018], and Walker et al. [2017]. This is supported by intermingling of the wall rocks in the brecciated zone.

Pallister et al. [2012] also suggest entrainment of the wall rocks in the conduit margin based on chemical compositions. These observations strongly suggest that the obsidian lithofacies of Shiroyama lava correspond to a dissected-shallow conduit or a spine inherited the structure from the conduit. In either case, the obsidian lithofacies of Shiroyama lava must preserve the structure of the shallow conduit.

The foliation and lineation of both sides of the obsidians appear to have been transported nearly vertically from below the Kannonzaki crater and away from each other (Figure 8B), indicating that they underwent petallike expansion during extrusion. In the inner massive obsidian zone, the concentration of the larger andesite xenoliths is more observable than in the marginal brecciated obsidian zone (Figure 9C). This suggests that the xenoliths were segregated into the interior of the conduit due to the frictional-strain gradient during the magma ascent.

5.4 Outgassing and structural development of the obsidian lithofacies

In the massive obsidian zone, the patchy pumiceous structure is characteristically developed (Figure 9D). Its vague outlines demonstrate that the pumiceous parts do not originate from the entrained clasts of the wall rocks but in situ vesiculation of the obsidian, which would have been induced by decompression associated with magma ascent.

Fracture networks developed in the obsidian lithofacies are mostly healed, and the healed fractures are subsequently deformed in a ductile manner into flow banding (Figure 10). In the sheared brecciated obsidian zone, the obsidian is brecciated, and the clasts are subsequently elongated. These occurrences are records of the repetition of brittle and ductile deformation of the obsidian and illustrate that their brittle deformation occurred above the glass transition temperature. The brittle and ductile behavior of a high-viscosity melt such as rhyolitic composition are governed by temperature as well as strain rate [Dingwell 1996; Tuffen and Dingwell 2004]. The obsidian is fractured during the glass transition by a high strain rate pulse. After the strain rate decreased, the fractures become welded. The repetition of melt fracturing and ductile deformation has been described from a shallow conduit and lava [e.g. Furukawa et al. 2019; Tuffen and Dingwell 2004]. Similarly, the obsidian of Shiroyama lava would be fractured by transient increase of the flow-induced shear stress within the conduit, resulting in the formation of the fracture network. The diffusive loss of water toward the fractures would have occurred, as suggested by Yoshimura and Nakamura [2010] and Cabrera et al. [2015], and the volcanic gases were removed, accompanied by pyroclastic materials, through the fractures [e.g. Okumura et al. 2010; Tuffen et al. 2003]. Transient pyroclastic channels called tuffisites have been reported [Castro et al. 2012a; Furukawa et al. 2019; Kendrick et al. 2016; Stasiuk et al. 1996; Tuffen et al. 2003]. When the fractures cut the volatile-filled pumiceous parts in the obsidian, outgassing from the bubbles also progresses. The gases are transported by permeable flow and are removed through wall rocks [Jaupart and Allègre 1991; Stasiuk et al. 1996]. Because the removal of hydrogen gas would promote oxidation accompanied by hematite formation [Furukawa et al. 2010], the reddish color, indicating hematite formation, of the matrix of the marginal brecciated and sheared brecciated obsidian zones would be caused by preferential outgassing.

We obtained the results of the lower water contents along the healed fracture of the obsidian (Figure 16). They must be the consequence of selective degassing (Figure 10A and Figure 16A). The formation of thin obsidian layers along the fractures via degassing has been experimentally recognized [Yoshimura and Nakamura 2010]. Fracture healing has been promoted by decreasing the strain rate and increasing temperature by frictional heating [Tuffen and Dingwell 2004]. In the obsidian distant from the fractures, vesiculation was induced due to the higher water content resulting in the obsidian with a light gray color (Figure 10A). 
Subsequently, the conduit obsidian would be deformed in a ductile manner under low strain rate conditions. The deformation caused elongation and folding of the bubble-free black- and vesicular light gray obsidians. Thus, the repetition of brittle and ductile deformations of the obsidian lead to development of the flow banding [Gonnermann and Manga 2003]. In Shiroyama lava, the flow banding defined by the difference in vesiculation is recognized not only from the obsidian lithofacies of the conduit but also the vesicular lithofacies of the lava. Hence, pervasive flow banding is considered to be inherited from the structure developed within the conduit. The formation process of the flow bands is different from that described by Furukawa and Uno [2015], who reported that they were originated from the ductile-brittle tearing of lava.

Although we cannot discuss from our data whether sintering of pyroclastic products of deeper cryptic fragmentation formed a dense magma at the conduit walls [Wadsworth et al. 2020], gas removal via vesiculation, fracturing, and brecciation of the magma in the conduit may have suppressed the explosivity, allowing formation of the dense obsidian.

5.5 Outgassing and structural development of the vesicular lithofacies

The density variation shows an abrupt decrease from the conduit obsidian (site 1 of Figure 15A) to the vesicular lava (site 2) and subsequent increase toward the distal part (sites 8 and 9). Because there are likely no chemical differences among the samples, the variation is consistent with vesicularity variation. Thus, vesiculation was promoted just after the effusion of the lava due to the pressure decreasing. The vesicularity of the lava in site 2 shows a high vesicularity of $70-80 \%$. Such high vesicularity promotes bubble coalescence (Figure 13D) and allows the lava to have high permeability [e.g. Eichelberger et al. 1986; Martel and Iacono-Marziano 2015; Westrich and Eichelberger 1994]. The abrupt decreasing of $\mathrm{OH}$ concentration (Figure $15 \mathrm{C}$ ) strongly indicate that the volatiles of the lava would have been removed effectively via networks of interconnected bubbles as permeable flow [e.g. Eichelberger et al. 1986; Okumura et al. 2009; Rust et al. 2004]. Outgassing allows stress from overburden to collapse the foam [Eichelberger et al. 1986]. A gradual increase in the apparent density with the flow distance indicates the incremental foam collapse (Figure 15B).

\subsection{Flow dynamics of Shiroyama lava}

The AMS fabric of site 2, which is near the vent area, shows that the principal susceptibility axes have a broad distribution (Figure 18B). Because the AMS fabric of silicic lava is considered to mirror the crystal preferred orientations [Cañón-Tapia and Castro 2004], the AMS fabric of site 2 means that the lava did not move in one direction at the emplacement. We interpret that the AMS fabric resulted from the lava inflation occurring just after extrusion. Because lava inflation likely caused the complicated local strain, the crystals in the lava would not be aligned well. The inflation of the lava would have also caused the broadly scattered AMS ellipsoid between oblate and prolate in shape (Figure 18A). At sites 5 and 6, the AMS foliation planes coincide with their flow-foliation planes (Figure 18C and 18D). The results indicate that an imbricated microlite alignment against the flow-foliation plane did not develop in the sites. Flow types such as simple or pure shear can be identified from crystal fabrics [e.g. Castro et al. 2002b; Iezzi and Ventura 2002; Manga 1998]. In simple shear, the crystal preferred orientation tends to be oriented at an angle to the flow foliation [Castro et al. 2002b; Manga 1998]. Thus, the coincidence between the AMS foliation plane and the flow-foliation plane shows that the flow types at sites 5 and 6 were dominated by pure shear rather than simple shear. Since it has been experimentally confirmed that the AMS ellipsoids develop prolate shapes within simple shear flows [Arbaret et al. 2013], the oblate shape of the AMS ellipsoid at sites 5 and 6 (Figure 18A) also supports their dominance of pure shear. The dominance of pure shear in a silicic lava has been recognized by Castro et al. [2002b] and Befus et al. [2015], and they interpreted that the pure shear strain was induced by the gravity collapse of the foams. This process is consistent with the results of microscopic observations and density measurement of Shiroyama lava. The $k_{\max }$ axes of the sites indicate nearly the EW direction (Figure 18C and $18 \mathrm{D})$, which is normal to the expected main flow direction. Because the microlite long axes are likely to be aligned in the extension direction within the pure shear flow [Manga 1998], the lava was stretched perpendicular to the main flow direction. These characteristics are interpreted to be a result of the concentric spreading of the lava [Merle 1998], and the motion would have formed the fan-shaped morphology of the lava.

Sites 8 and 9 correspond to the distal part of the lava. The characteristics of the AMS fabrics and ellipsoids are different from those of sites 5 and 6 (Figure 18A, E, and F). The AMS fabrics of the sites show that the principal susceptibility axes have a broad distribution. The AMS ellipsoids are broadly scattered between oblate and prolate shapes. The alteration of the AMS is likely caused by pressure from the inner moving lava to the immobile distal lava. The systematic alignment of microlites generated within the flowing lava (sites 5 and 6) become disturbed in the distal pressurized lava. The AMS ellipsoids at sites 8 and 9 were partly developed to prolate in shape. The prolate shape may be attributed to the increasing of the simple shear component in the distal part of a lava as suggested by Smith and Houston [1994] and Castro et al. [2002b]. 


\subsection{Emplacement process of Shiroyama lava}

The volcanic activity of rhyolite magma in the Shiroyama Volcano commenced around the coastline. We consider that a pyroclastic cone, composed of the unconsolidated Kannonzaki pyroclastic rocks, had been formed on the Kannonzaki crater, preceded by the emergence of Shiroyama lava. Deformation of the Kannonzaki pyroclastic rocks at the boundary with Shiroyama lava (Figure 12B) would have been a consequence of pressure associated with the advancement of Shiroyama lava, and subsequent thermal transfer from the lava must have caused preferential hightemperature oxidation of the marginal and infiltrated parts of the Kannonzaki pyroclastic rocks. Shiroyama lava, overlies the Kannonzaki pyroclastic rocks, and the lack of the Kannonzaki pyroclastic rocks above Shiroyama lava also support the sequence. The proposed volcanic succession is different from that reported by Itoh [1989], who suggested that the activity of the Kannonzaki crater was initiated after the emplacement of Shiroyama lava.

The Kannonzaki pyroclastic rocks include clasts of obsidian lava, perlitic lava, and pyroclastic rocks containing perlitic lava clasts, indicating repeated emergence and destruction of the lava. The activity may resemble the hybrid explosive-effusive eruption, which was directly observed by Schipper et al. [2013] in the vent of the 2011-2012 eruption at Cordón Caulle volcano, Chile. They observed that Vulcanian blasts and effusion of the obsidian lava had occurred synchronously from the common vent system. The eruption system provided abundant ash and lava bombs simultaneously. The Kannonzaki pyroclastic rocks may have been formed by such eruption style. The volcanic activity of the Kannonzaki crater eventually formed a pyroclastic cone, mostly above sea level. The conduit magma subsequently changed the ascent direction to the north of the crater. The shift of the magma ascent direction probably caused concentric depression of the pyroclastic cone. The northern part of the pyroclastic cone was deformed with portions rotated to vertical orientations by the intrusion of the following magma. Removal of the volcanic gases via vesiculation, fracturing, and brecciation from the conduit magma may have played a role in suppressing the explosivity, and the magma could be effused as a dense obsidian lava. The lava flowed southward on wet sediments, and the pyroclastic cone was deformed by pressure from the advancing lava. The contact zone of the pyroclastic rocks with lava was oxidized.

Since the lava originally maintained some extent of water, the lava effervesced just after the effusion. Bubbles at site 2 show a spherical shape, and there are two possible explanations about the formation of the spherical bubbles. First, they were formed in the condition of no significant motion of the lava. Secondary, the elongated bubbles were initially formed by shear deformation of the lava. The lava was, subsequently, stagnated for sufficient time for the bubbles to relax to a spherical shape. In either way, the vesiculation led to pervasive bubble coalescence, resulting in the formation of abundant permeable pathways, and effective gas removal was promoted. As a result of the extensive outgassing, the inflation of the lava shifted to deflation due to the gravity collapse or the interfacial tension-driven relaxation [Otsuki et al. 2015] of the foams. The flow resulted in the concentric spreading of the lava. The bubbles were elongated by flow-induced pure shear. Because the elongated bubbles are comparatively easy to connect [Okumura et al. 2008], additional outgassing occurs via the interconnected bubbles. With the progression of the removal of gases during foam collapse, the density and viscosity of the lava might have increased, and the distal lava eventually lost mobility. The immobile distal lava was deformed during the glass transition in both brittle and ductile manners owing to pressure from the advancing inner lava.

\section{Conclusions}

We present a geological description, density variation, FTIR results, and magnetic characteristics of the Pleistocene Shiroyama rhyolite lava on Himeshima Island, Japan. We illustrated the conduit system, degassing and flow dynamics of Shiroyama lava.

The lava was mainly divided into locally developed obsidian and vesicular lithofacies. We interpreted that the obsidian lithofacies corresponded to the shallow conduit based on the structural variation. Removal of the volcanic gases via vesiculation, fracturing, and brecciation from the conduit magma may have played a role in suppressing the explosivity, and the magma could be effused as a dense obsidian lava. Since the lava originally maintained some extent of water, the lava effervesced just after the effusion. The extensive effervescence caused pervasive bubble coalescence, resulting in the formation of abundant permeable pathways. Therefore, the volcanic gasses were removed from the inflated lava. As a result, the lava shifted to deflation due to foam collapse. The flow resulted in the concentric spreading of the lava.

\section{Acknowledgements}

We wish to thank K. Tani, K. Sano, and H. Shimoyama for their advice and assistance with FTIR analysis. Density measurements were performed with the help of T. Kanamaru. We also appreciate T. Haraguchi for drone photo. This study was supported by a Grant-in-Aid for Scientific Research (15K05313, 15K05342, 19K04001) from the Japan Society for the Promotion of Science. The authors would like to thanks to F.B. Wadsworth for editorial handling of the manuscript. The constructive comments of B.J. Andrews and two anonymous reviewers are also appreciated. 


\section{Author COnTRibutions}

KF led the project and drafted the manuscript with help from all authors. A field survey and magnetic susceptibility measurements were conducted by KF, KU, and YH. Density measurements were done by KF. KF and MT carried FTIR analyses. AMS analyses were done by KU and SM. All authors contributed to model development and interpretations.

\section{Data AVAilability}

All data used in this study are presented in Tables A1 and A2. The authors can provide also geological data upon request.

\section{Copyright NOTICE}

(C) The Author(s) 2021. This article is distributed under the terms of the Creative Commons Attribution 4.0 International License, which permits unrestricted use, distribution, and reproduction in any medium, provided you give appropriate credit to the original author(s) and the source, provide a link to the Creative Commons license, and indicate if changes were made.

\section{REFERENCES}

Andrews, G. D., S. M. Kenderes, A. G. Whittington, S. L. Isom, S. R. Brown, H. D. Pettus, B. G. Cole, and K. J. Gokey (2021). "The fold illusion: The origins and implications of ogives on silicic lavas". Earth and Planetary Science Letters 553, p. 116643. DoI: 10.1016/j . eps1.2020.116643.

Arbaret, L., P. Launeau, H. Diot, and S. Sizaret (2013). "Magnetic and shape fabrics of magnetite in simple shear flows". Journal of Volcanology and Geothermal Research 249, pp. 25-38. DoI: 10.1016/j . jvolgeores . 2012.09.003.

Befus, K. S., M. Manga, J. E. Gardner, and M. Williams (2015). "Ascent and emplacement dynamics of obsidian lavas inferred from microlite textures". Bulletin of Volcanology 77.10. DoI: 10.1007/s00445-015-0971-6.

Bullock, L. A., R. Gertisser, and B. O'Driscoll (2018). "Emplacement of the Rocche Rosse rhyolite lava flow (Lipari, Aeolian Islands)". Bulletin of Volcanology 80.5. Dor: $10.1007 / \mathrm{s} 00445-018-1222-4$.

Cabrera, A., R. F. Weinberg, and H. M. Wright (2015). "Magma fracturing and degassing associated with obsidian formation: The explosive-effusive transition". Journal of Volcanology and Geothermal Research 298, pp. 71-84. DoI: $10.1016 / \mathrm{j}$. jvolgeores . 2014. 12.014 .

Cañón-Tapia, E. and R. Mendoza-Borunda (2014). "Magnetic petrofabric of igneous rocks: Lessons from pyroclastic density current deposits and obsidians".
Journal of Volcanology and Geothermal Research 289, pp. 151-169. Dor: 10.1016/j . jvolgeores . 2014 . 11 . 006.

Cañón-Tapia, E. and J. Castro (2004). "AMS measurements on obsidian from the Inyo Domes, CA: a comparison of magnetic and mineral preferred orientation fabrics". Journal of Volcanology and Geothermal Research 134.3, pp. 169-182. Dor: $10.1016 / j$. jvolgeores. 2004.01.005.

Cas, R. and J. Wright (1987). Volcanic successions modern and ancient: A geological approach to processes, products and successions. Chapman \& Hall. IsBN: 978-0-41244640-5.

Castro, J. M., I. N. Bindeman, H. Tuffen, and C. Ian Schipper (2014). "Explosive origin of silicic lava: Textural and $\delta \mathrm{D}-\mathrm{H} 2 \mathrm{O}$ evidence for pyroclastic degassing during rhyolite effusion". Earth and Planetary Science Letters 405, pp. 52-61. DoI: 10.1016/j . epsl. 2014.08.012.

Castro, J. M., A. Burgisser, C. I. Schipper, and S. Mancini (2012a). "Mechanisms of bubble coalescence in silicic magmas". Bulletin of Volcanology 74.10, pp. 2339-2352. DoI: 10 . 1007 / s00445-012 0666-1.

Castro, J. M., B. Cordonnier, H. Tuffen, M. J. Tobin, L. Puskar, M. C. Martin, and H. A. Bechtel (2012b). "The role of melt-fracture degassing in defusing explosive rhyolite eruptions at volcán Chaitén". Earth and Planetary Science Letters 333-334, pp. 63-69. DoI: 10.1016/j. eps1.2012.04.024.

Castro, J. M. and D. B. Dingwell (2009). "Rapid ascent of rhyolitic magma at Chaitén volcano, Chile". Nature 461.7265, pp. 780-783. DoI: $10.1038 /$ nature 08458 .

Castro, J. M., M. Manga, and M. C. Martin (2005). "Vesiculation rates of obsidian domes inferred from $\mathrm{H} 2 \mathrm{O}$ concentration profiles". Geophysical Research Letters 32.21. DoI: 10.1029/2005g1024029.

Castro, J. and K. V. Cashman (1999). "Constraints on rheology of obsidian lavas based on mesoscopic folds". Journal of Structural Geology 21.7, pp. 807819. Dor: 10.1016/s0191-8141(99) 00070-x.

Castro, J., K. Cashman, N. Joslin, and B. Olmsted (2002a). "Structural origin of large gas cavities in the Big Obsidian Flow, Newberry Volcano". Journal of Volcanology and Geothermal Research 114.3-4, pp. 313-330. Dor: 10.1016/s0377-0273 (01) 00296-7.

Castro, J., M. Manga, and K. Cashman (2002b). "Dynamics of obsidian flows inferred from microstructures: insights from microlite preferred orientations". Earth and Planetary Science Letters 199.1-2, pp. 211-226. DoI: 10.1016/s0012-821x(02) 00559-9.

Denton, J., H. Tuffen, and J. Gilbert (2012). "Variations in hydration within perlitised rhyolitic lavas-evidence from Torfajökull, Iceland". Journal of Volcanology and Geothermal Research 223-224, pp. 64-73. Dor: 10.1016/j . jvolgeores. 2012 .02 .005. 
Dingwell, D. B. (1996). "Volcanic Dilemma-Flow or Blow?" Science 273.5278, pp. 1054-1055. DoI: 10 . 1126/science.273.5278.1054.

Eichelberger, J. C., C. R. Carrigan, H. R. Westrich, and R. H. Price (1986). "Non-explosive silicic volcanism". Nature 323.6089, pp. 598-602. DoI: $10.1038 /$ 323598a0.

Farquharson, J., M. James, and H. Tuffen (2015). "Examining rhyolite lava flow dynamics through photobased 3D reconstructions of the 2011-2012 lava flowfield at Cordón-Caulle, Chile". Journal of Volcanology and Geothermal Research 304, pp. 336-348. DoI: 10.1016/j . jvolgeores. 2015.09.004.

Fink, J. (1980). "Surface folding and viscosity of rhyolite flows". Geology 8.5, p. 250. DoI: $10.1130 / 0091$ 7613(1980) 8<250: sfavor $>2$. 0. co; 2 .

Fink, J. H., S. W. Anderson, and C. R. Manley (1992). "Textural constraints on effusive silicic volcanism: Beyond the permeable foam model". Journal of Geophysical Research 97.B6, p. 9073. DOI: $10.1029 /$ $92 \mathrm{jb} \odot 0416$.

Fink, J. H. and C. R. Manley (1987). "Origin of pumiceous and glassy textures in rhyolite flows and domes". The Emplacement of Silicic Domes and Lava Flows, pp. 77-88. Dor: 10.1130/spe212-p77.

Furukawa, K. and K. Uno (2015). "Origin and deformation of high porosity bands in the Takanoobane Rhyolite lava of Aso volcano, Japan". Journal of Volcanology and Geothermal Research 305, pp. 76-83. DoI: 10.1016/j . jvolgeores. 2015.09.021.

Furukawa, K., K. Uno, T. Kanamaru, and K. Nakai (2019). "Structural variation and the development of thick rhyolite lava: A case study of the Sanukayama rhyolite lava on Kozushima Island, Japan". Journal of Volcanology and Geothermal Research 369, pp. 1-20. Dor: $10.1016 / \mathrm{j}$. jvolgeores.2018.11.001.

Furukawa, K., K. Uno, and I. Miyagi (2010). "Mechanisms of oxidation and degassing in the Takanoobane rhyolite lava of Aso Volcano, Japan". Journal of Volcanology and Geothermal Research 198.3-4, pp. 348354. Dor: $10.1016 / \mathrm{j}$. jvolgeores. 2010.09.015.

Gaunt, H. E., P. R. Sammonds, P. G. Meredith, R. Smith, and J. S. Pallister (2014). "Pathways for degassing during the lava dome eruption of Mount St. Helens 2004-2008". Geology 42.11, pp. 947-950. DOI: 10 . $1130 / \mathrm{g} 35940.1$.

Giachetti, T., H. M. Gonnermann, J. E. Gardner, T. Shea, and A. Gouldstone (2015). "Discriminating secondary from magmatic water in rhyolitic matrixglass of volcanic pyroclasts using thermogravimetric analysis". Geochimica et Cosmochimica Acta 148, pp. 457-476. DoI: 10.1016/j.gca.2014.10.017.

Gonnermann, H. M. and M. Manga (2003). "Explosive volcanism may not be an inevitable consequence of magma fragmentation". Nature 426.6965, pp. 432435. DoI: $10.1038 /$ nature 02138 .

Gregg, T. K. (2017). "Patterns and processes: Subaerial lava flow morphologies: A review". Journal of Vol- canology and Geothermal Research 342, pp. 3-12. Dor: 10.1016/j. jvolgeores. 2017.04.022.

Heap, M. J., H. Tuffen, F. B. Wadsworth, T. Reuschlé, J. M. Castro, and C. I. Schipper (2019). "The Permeability Evolution of Tuffisites and Implications for Outgassing Through Dense Rhyolitic Magma". Journal of Geophysical Research: Solid Earth 124.8, pp. 8281-8299. Dor: 10.1029/2018jb017035.

Hornby, A. J., J. E. Kendrick, O. D. Lamb, T. Hirose, S. De Angelis, F. W. von Aulock, K. Umakoshi, T. Miwa, S. Henton De Angelis, F. B. Wadsworth, and et al. (2015). "Spine growth and seismogenic faulting at Mt. Unzen, Japan”. Journal of Geophysical Research: Solid Earth 120.6, pp. 4034-4054. Dor: 10 . 1002 / $2014 j b 011660$.

Iezzi, G. and G. Ventura (2002). "Crystal fabric evolution in lava flows: results from numerical simulations". Earth and Planetary Science Letters 200.1-2, pp. 33-46. DOI: 10.1016/s0012-821x (02) $00617-9$.

Ishikawa, T. and K. Kamada (2009). "Fragmentation textures of rhyolitic lava flows due to the shear stress: An example of Hime-shima Volcanic Group, northeastern Kyusyu, Japan”. Programme and Abstracts, the Volcanological Society of Japan. Volcanological Society of Japan, p. 5. DoI: 10.18940/vsj.2009. $0_{-} 5$. [In Japanese].

Itoh, J., H. Hoshizumi, and T. Iwaya (1997). Geology of the Hime Shima district. [Geological Sheet Map at 1 : 50,000; in Japanese, with English Abstract].

Itoh, J. (1989). "Geology and volcanic activity of the Himeshima volcanic group, north Kyushu, Japan". Bulletin of the Volcanological Society of Japan 34, pp. 117. DoI: 10.18940/kazanc.34.1_1. [In Japanese with English abstract].

- (1990). "Petrology of Hime-shima volcanic group". Journal of Mineralogy, Petrology and Economic Geology 85.12, pp. 541-558. DoI: $10.2465 /$ ganko.85.541. [In Japanese with English abstract].

Jaupart, C. and C. J. Allègre (1991). "Gas content, eruption rate and instabilities of eruption regime in silicic volcanoes". Earth and Planetary Science Letters 102.34, pp. 413-429. Dor: 10.1016/0012-821x(91)90032-d. Kamata, H. (1988). "Formation age of the volcanic front in central Kyushu and western Chugoku, Japan”. The Earth Monthly 10, pp. 568-574.

Kaneoka, I. and M. Suzuki (1970). "Dating of Obsidian by K-Ar and Fission Track Dating". Journal of the Geological Society of Japan 76.6, pp. 309-313. Dor: 10.5575/geosoc. 76.309.

Kano, K. (1991). "Volcaniclastic sedimentation in a shallow-water marginal basin: the Early Miocene Koura Formation, SW Japan". Sedimentary Geology 74.1-4, pp. 309-321. DoI: $10.1016 / 0037-0738$ (91) 90070-t.

Kasama, T. and K. Huzita (1955). "On the geologic structure and the volcanic activity of Himesima, Oita Prefecture". The Journal of the Geological Society of Japan 61, pp. 249-257. Dor: 10.5575/geosoc.61.249. [In Japanese with English abstract]. 
Kendrick, J. E., Y. Lavallée, N. R. Varley, F. B. Wadsworth, O. D. Lamb, and J. Vasseur (2016). "Blowing Off Steam: Tuffisite Formation As a Regulator for Lava Dome Eruptions". Frontiers in Earth Science 4. DoI: 10.3389/feart.2016.00041.

Lamb, O. D., S. De Angelis, K. Umakoshi, A. J. Hornby, J. E. Kendrick, and Y. Lavallée (2015). "Repetitive fracturing during spine extrusion at Unzen volcano, Japan". Solid Earth 6.4, pp. 1277-1293. DoI: 10.5194/ se-6-1277-2015.

Lara, L. E. (2009). "The 2008 eruption of the Chaitén Volcano, Chile: a preliminary report". Andean Geology 36.1, pp. 125-129.

Magnall, N., M. R. James, H. Tuffen, and C. Vye-Brown (2017). "Emplacing a Cooling-Limited Rhyolite Lava Flow: Similarities with Basaltic Lava Flows". Frontiers in Earth Science 5. Dor: 10.3389 / feart. 2017. 00044 .

Magnall, N., M. R. James, H. Tuffen, C. Vye-Brown, C. I. Schipper, J. M. Castro, and A. G. Davies (2018). "The origin and evolution of breakouts in a coolinglimited rhyolite lava flow". GSA Bulletin 131.1-2, pp. 137-154. Dor: 10.1130/b31931.1.

Manga, M. (1998). "Orientation distribution of microlites in obsidian". Journal of Volcanology and Geothermal Research 86.1-4, pp. 107-115. DOI: 10.1016 / s0377-0273 (98) $00084-5$.

Manley, C. R. and J. H. Fink (1987). "Internal textures of rhyolite flows as revealed by research drilling". Geology 15.6, p. 549. Dor: 10.1130/0091-7613(1987) $15<549$ : itorfa $>2.0$. co; 2 .

Martel, C. and G. Iacono-Marziano (2015). "Timescales of bubble coalescence, outgassing, and foam collapse in decompressed rhyolitic melts". Earth and Planetary Science Letters 412, pp. 173-185. DoI: $10.1016 / \mathrm{j}$. eps1.2014.12.010.

Matsumoto, A., J. Itoh, H. Hoshizumi, and Y. Ohta (2010). "KAr and 40Ar / 39Ar Ages of Himeshima Volcanic Group, Kyushu, Japan". Programme and Abstracts, the Volcanological Society of Japan. Volcanological Society of Japan, p. 132. DoI: 10.18940/vsj . 2010.0_132. [In Japanese].

McIntosh, I., E. Llewellin, M. Humphreys, A. Nichols, A. Burgisser, C. Schipper, and J. Larsen (2014). "Distribution of dissolved water in magmatic glass records growth and resorption of bubbles". Earth and Planetary Science Letters 401, pp. 1-11. Dor: 10.1016/ j.epsl.2014.05.037.

McIntosh, I. M., A. R. Nichols, K. Tani, and E. W. Llewellin (2017). "Accounting for the speciesdependence of the $3500 \mathrm{~cm} 1 \mathrm{H} 2$ Otinfrared molar absorptivity coefficient: Implications for hydrated volcanic glasses". American Mineralogist 102.8, pp. 1677-1689. DoI: 10.2138/am-2017-5952ccby.

McLean, C. E., D. J. Brown, and H. J. Rawcliffe (2016). "Extensive soft-sediment deformation and peperite formation at the base of a rhyolite lava: Owyhee Mountains, SW Idaho, USA". Bulletin of Volcanology 78.6. DoI: $10.1007 / \mathrm{s} 00445-016-1035-2$.
Merle, O. (1998). "Internal strain within lava flows from analogue modelling". Journal of Volcanology and Geothermal Research 81.3-4, pp. 189-206. DoI: 10 . 1016/s0377-0273(98)00009-2.

Mitchell, S. J., I. M. McIntosh, B. F. Houghton, R. J. Carey, and T. Shea (2018). "Dynamics of a powerful deep submarine eruption recorded in $\mathrm{H} 2 \mathrm{O}$ contents and speciation in rhyolitic glass: The 2012 Havre eruption". Earth and Planetary Science Letters 494, pp. 135-147. DoI: 10.1016/j . eps1.2018.04.053.

Nakada, S., H. Shimizu, and K. Ohta (1999). "Overview of the 1990-1995 eruption at Unzen Volcano". Journal of Volcanology and Geothermal Research 89.1-4, pp. 1-22. DoI: 10.1016/s0377-0273(98)00118-8.

Nakada, S., A. Zaennudin, M. Yoshimoto, F. Maeno, Y. Suzuki, N. Hokanishi, H. Sasaki, M. Iguchi, T. Ohkura, H. Gunawan, and et al. (2019). "Growth process of the lava dome/flow complex at Sinabung Volcano during 2013-2016". Journal of Volcanology and Geothermal Research 382, pp. 120-136. DoI: 10 . 1016/j. jvolgeores.2017.06.012.

Okumura, S., M. Nakamura, T. Nakano, K. Uesugi, and A. Tsuchiyama (2010). "Shear deformation experiments on vesicular rhyolite: Implications for brittle fracturing, degassing, and compaction of magmas in volcanic conduits". Journal of Geophysical Research 115.B6. DOI: $10.1029 / 2009$ jb006904.

Okumura, S., M. Nakamura, S. Takeuchi, A. Tsuchiyama, T. Nakano, and K. Uesugi (2009). "Magma deformation may induce non-explosive volcanism via degassing through bubble networks". Earth and Planetary Science Letters 281.3-4, pp. 267274. DoI: $10.1016 /$ j.epsl.2009.02.036.

Okumura, S., M. Nakamura, A. Tsuchiyama, T. Nakano, and K. Uesugi (2008). "Evolution of bubble microstructure in sheared rhyolite: Formation of a channel-like bubble network". Journal of Geophysical Research 113.B7. DoI: 10.1029/2007jb005362.

Otsuki, S., M. Nakamura, S. Okumura, and O. Sasaki (2015). "Interfacial tension-driven relaxation of magma foam: An experimental study". Journal of Geophysical Research: Solid Earth 120.11, pp. 74037424. DOI: $10.1002 / 2015 \mathrm{jb} 012391$.

Pallister, J. S., K. V. Cashman, J. T. Hagstrum, N. M. Beeler, S. C. Moran, and R. P. Denlinger (2012). "Faulting within the Mount St. Helens conduit and implications for volcanic earthquakes". Geological Society of America Bulletin 125.3-4, pp. 359-376. DoI: $10.1130 / \mathrm{b} 30716.1$.

Ramsey, M. S. and J. H. Fink (1999). "Estimating silicic lava vesicularity with thermal remote sensing: a new technique for volcanic mapping and monitoring". Bulletin of Volcanology 61.1-2, pp. 32-39. Dor: 10.1007/s004450050260.

Rust, A., K. Cashman, and P. Wallace (2004). "Magma degassing buffered by vapor flow through brecciated conduit margins". Geology 32.4, p. 349. Dor: 10.1130/ g20388.2. 
Ryan, A. G., J. K. Russell, M. J. Heap, S. Kolzenburg, A. Vona, and A. R. L. Kushnir (2019). "StrainDependent Rheology of Silicate Melt Foams: Importance for Outgassing of Silicic Lavas". Journal of Geophysical Research: Solid Earth 124.8, pp. 8167-8186. DoI: 10.1029/2019jb018099.

Ryan, A. G., M. J. Heap, J. K. Russell, L. A. Kennedy, and M. A. Clynne (2020). "Cyclic shear zone cataclasis and sintering during lava dome extrusion: Insights from Chaos Crags, Lassen Volcanic Center (USA)". Journal of Volcanology and Geothermal Research 401, p. 106935. DoI: 10.1016/j . jvolgeores.2020.106935.

Sano, K., K. Wada, and E. Sato (2015). "Rates of water exsolution and magma ascent inferred from microstructures and chemical analyses of the Tokachi-Ishizawa obsidian lava, Shirataki, northern Hokkaido, Japan". Journal of Volcanology and Geothermal Research 292, pp. 29-40. DoI: $10.1016 / \mathrm{j}$. jvolgeores.2014.11.015.

Sasaki, T. and Y. Katsui (1981). "A new technique for measuring density of pumice using glass beads". Bulletin of the Volcanological Society of Japan 2, pp. 117118. DoI: $10.18940 / \mathrm{kazanc} .26 .2 \_117$. [In Japanese with English abstract].

Saubin, E., H. Tuffen, L. Gurioli, J. Owen, J. M. Castro, K. Berlo, E. M. McGowan, C. I. Schipper, and K. Wehbe (2016). "Conduit Dynamics in Transitional Rhyolitic Activity Recorded by Tuffisite Vein Textures from the 2008-2009 Chaitén Eruption". Frontiers in Earth Science 4. DoI: 10.3389/feart.2016.00059.

Schipper, C. I., J. M. Castro, H. Tuffen, M. R. James, and P. How (2013). "Shallow vent architecture during hybrid explosive-effusive activity at Cordón Caulle (Chile, 2011-12): Evidence from direct observations and pyroclast textures". Journal of Volcanology and Geothermal Research 262, pp. 25-37. Dor: 10.1016/j . jvolgeores.2013.06.005.

Shields, J., H. Mader, L. Caricchi, H. Tuffen, S. Mueller, M. Pistone, and L. Baumgartner (2016). "Unravelling textural heterogeneity in obsidian: Shear-induced outgassing in the Rocche Rosse flow". Journal of Volcanology and Geothermal Research 310, pp. 137-158. Dor: $10.1016 / \mathrm{j}$. jvolgeores. 2015.12.003.

Simões, M., E. Lima, C. Sommer, and L. Rossetti (2018). "Structures and lithofacies of inferred silicic conduits in the Paraná-Etendeka LIP, southernmost Brazil". Journal of Volcanology and Geothermal Research 355, pp. 319-336. Dor: 10.1016/j . jvolgeores. 2017. 12 . 013.

Smith, J. V. and E. C. Houston (1994). "Folds produced by gravity spreading of a banded rhyolite lava flow". Journal of Volcanology and Geothermal Research 63.1-2, pp. 89-94. Dor: 10.1016/0377-0273(94)90019-1.

Sparks, Murphy, Lejeune, Watts, Barclay, and Young (2000). "Control on the emplacement of the andesite lava dome of the Soufriere Hills volcano, Montserrat by degassing-induced crystallization". Terra Nova 12.1, pp. 14-20. DOI: $10.1046 /$ j . 1365-3121. 2000 . ๑०267.x.
Stasiuk, M. V., J. Barclay, M. R. Carroll, C. Jaupart, J. C. Ratté, R. S. J. Sparks, and S. R. Tait (1996). "Degassing during magma ascent in the Mule Creek vent (USA)". Bulletin of Volcanology 58.2-3, pp. 117-130. DOI: $10.1007 / \mathrm{s} 004450050130$.

Stevenson, R. J., R. M. Briggs, and A. P. W. Hodder (1994). "Physical volcanology and emplacement history of the Ben Lomond rhyolite lava flow, Taupo Volcanic Centre, New Zealand". New Zealand Journal of Geology and Geophysics 37.3, pp. 345-358. Dor: 10 . 1080/00288306.1994.9514625.

Taniguchi, H. (1982). "Process for the formation of felsic spiracles in Menbo lava, Kozushiman". Bulletin of the Volcanological Society of Japan 27, pp. 249-260. DoI: $10.18940 /$ kazanc. 27.4 _249. [In Japanese with English abstract].

Taylor, B. E., J. C. Eichelberger, and H. R. Westrich (1983). "Hydrogen isotopic evidence of rhyolitic magma degassing during shallow intrusion and eruption". Nature 306.5943, pp. 541-545. Dor: 10 . 1038/306541a0.

Tolan, T. L., B. S. Martin, S. P. Reidel, J. L. Anderson, K. A. Lindsey, and W. Burt (2009). "An introduction to the stratigraphy, structural geology, and hydrogeology of the Columbia River Flood-Basalt ProvincesubtitleA primer for the GSA Columbia River Basalt Group field trips/subtitle". Volcanoes to Vineyards. Geological Society of America. Dor: 10 . 1130/2009. fld015 (28).

Tuffen, H. and D. Dingwell (2004). "Fault textures in volcanic conduits: evidence for seismic trigger mechanisms during silicic eruptions". Bulletin of Volcanology 67.4, pp. 370-387. DOI: 10.1007 / s00445- $004-$ $0383-5$.

Tuffen, H., D. B. Dingwell, and H. Pinkerton (2003). "Repeated fracture and healing of silicic magma generate flow banding and earthquakes?" Geology 31.12, p. 1089. DoI: 10.1130/g19777.1.

Tuffen, H., M. R. James, J. M. Castro, and C. I. Schipper (2013). "Exceptional mobility of an advancing rhyolitic obsidian flow at Cordón Caulle volcano in Chile". Nature Communications 4.1. Dor: 10.1038/ ncomms 3709 .

Von Aulock, F., A. Nichols, B. Kennedy, and C. Oze (2013). "Timescales of texture development in a cooling lava dome". Geochimica et Cosmochimica Acta 114, pp. 72-80. Dor: 10.1016/j.gca.2013.03.012.

Wadsworth, F. B., E. W. Llewellin, J. Vasseur, J. E. Gardner, and H. Tuffen (2020). "Explosive-effusive volcanic eruption transitions caused by sintering". Science Advances 6.39, eaba7940. Dor: 10.1126/sciadv . aba7940.

Walker, R., M. Branney, and M. Norry (2017). "Dike propagation and magma flow in a glassy rhyolite dike: A structural and kinematic analysis". Geological Society of America Bulletin 129.5-6, pp. 594-606. DOI: $10.1130 / \mathrm{b} 31378.1$. 
Watkins, J., M. Manga, C. Huber, and M. Martin (2008). "Diffusion-controlled spherulite growth in obsidian inferred from $\mathrm{H} 2 \mathrm{O}$ concentration profiles". Contributions to Mineralogy and Petrology 157.2, pp. 281-281. Dor: $10.1007 / \mathrm{s} 00410-008-0340-\mathrm{y}$.

Westrich, H. R. and J. C. Eichelberger (1994). "Gas transport and bubble collapse in rhyolitic magma: an experimental approach". Bulletin of Volcanology 56.67, pp. 447-458. DOI: $10.1007 / \mathrm{bf0} 0302826$.

Wysoczanski, R. and K. Tani (2006). "Spectroscopic FTIR imaging of water species in silicic volcanic glasses and melt inclusions: An example from the Izu-Bonin arc". Journal of Volcanology and Geothermal Research 156.3-4, pp. 302-314. DoI: $10.1016 / j$. jvolgeores.2006.03.024.
Yamagishi, H. and Y. Goto (1992). "Cooling joints of subaqueous rhyolite lavas at Kuroiwa, Yakumo, southern Hokkaido, Japan”. Bulletin of the Volcanological Society of Japan 37.4, pp. 205-207. Dor: 10.18940/kazan.37.4_205. [In Japanese with English abstract].

Yoshimura, S. and M. Nakamura (2010). "Fracture healing in a magma: An experimental approach and implications for volcanic seismicity and degassing". Journal of Geophysical Research 115.B9. DOI: 10.1029/ $2009 \mathrm{jb} 000834$.

Zhang, Y., E. M. Stolper, and P. D. Ihinger (1995). "Kinetics of the reaction $\mathrm{H} 2 \mathrm{OO}=2 \mathrm{OH}$ in rhyolitic and albitic glasses preliminary results". American Mineralogist 80.5-6, pp. 593-612. DOI: $10.2138 /$ am-19955-618. 


\section{A Appendix 1}

Table A1: Values ( $\mathrm{Km}$, in $\mathrm{SI})$ and Directions ( $\mathrm{D}=$ Declination, $\mathrm{I}=$ Inclination, in degrees $\left.{ }^{\circ}\right)$ of the principal susceptibilities $\left(K_{\max }, K_{\text {int }}\right.$, and $\left.K_{\min }\right)$ of samples from Shiroyama lava; $T$ : shape parameter ( $T>0$ oblate, $T<0$ prolate); $P^{\prime}$ : degree of anisotropy.

\begin{tabular}{|c|c|c|c|c|c|c|c|c|c|c|}
\hline \multirow{2}{*}{ Site } & \multirow{2}{*}{ Sample name } & \multirow{2}{*}{$\mathrm{Km}$} & \multicolumn{2}{|c|}{$K_{\text {max }}$} & \multicolumn{2}{|c|}{$K_{\text {int }}$} & \multicolumn{2}{|c|}{$K_{\min }$} & \multirow[t]{2}{*}{$T$} & \multirow[t]{2}{*}{$P^{\prime}$} \\
\hline & & & $\mathrm{D}$ & I & $\mathrm{D}$ & I & $\mathrm{D}$ & I & & \\
\hline \multirow[t]{11}{*}{2} & $2-91 \mathrm{~A}$ & $4.22 \times 10^{-5}$ & 205 & 72 & 38 & 18 & 307 & 4 & -0.392 & 1.025 \\
\hline & $2-91 B$ & $3.17 \times 10^{-5}$ & 233 & 16 & 345 & 52 & 133 & 33 & 0.176 & 1.023 \\
\hline & $2-93 \mathrm{~A}$ & $8.67 \times 10^{-5}$ & 194 & 12 & 64 & 72 & 287 & 13 & 0.149 & 1.071 \\
\hline & $2-93 B$ & $5.45 \times 10^{-5}$ & 209 & 43 & 116 & 3 & 22 & 47 & -0.821 & 1.037 \\
\hline & $2-95 \mathrm{~A}$ & $2.71 \times 10^{-5}$ & 55 & 66 & 262 & 22 & 168 & 10 & 0.897 & 1.047 \\
\hline & $2-95 B$ & $2.51 \times 10^{-5}$ & 62 & 58 & 229 & 31 & 322 & 6 & 0.092 & 1.049 \\
\hline & $2-95 C$ & $2.62 \times 10^{-5}$ & 231 & 75 & 81 & 13 & 349 & 7 & 0.037 & 1.060 \\
\hline & $2-96 \mathrm{~A}$ & $5.73 \times 10^{-5}$ & 241 & 9 & 331 & 2 & 75 & 81 & -0.490 & 1.066 \\
\hline & $2-96 B$ & $6.14 \times 10^{-5}$ & 85 & 63 & 245 & 26 & 339 & 8 & -0.012 & 1.059 \\
\hline & $2-97 A$ & $6.24 \times 10^{-5}$ & 25 & 54 & 279 & 11 & 182 & 34 & -0.053 & 1.066 \\
\hline & $2-97 B$ & $5.22 \times 10^{-5}$ & 6 & 43 & 273 & 2 & 181 & 47 & 0.142 & 1.058 \\
\hline \multirow[t]{32}{*}{5} & 5-31A & $1.70 \times 10^{-4}$ & 149 & 27 & 243 & 8 & 348 & 61 & 0.764 & 1.209 \\
\hline & $5-31 B$ & $2.16 \times 10^{-4}$ & 37 & 34 & 138 & 17 & 250 & 51 & 0.727 & 1.210 \\
\hline & $5-32 \mathrm{~A}$ & $2.58 \times 10^{-4}$ & 48 & 34 & 146 & 12 & 252 & 54 & 0.771 & 1.214 \\
\hline & $5-32 B$ & $2.61 \times 10^{-4}$ & 56 & 36 & 150 & 6 & 248 & 54 & 0.772 & 1.250 \\
\hline & $5-32 C$ & $1.42 \times 10^{-4}$ & 60 & 34 & 153 & 5 & 250 & 56 & 0.772 & 1.192 \\
\hline & $5-32 D$ & $1.91 \times 10^{-4}$ & 65 & 36 & 334 & 1 & 244 & 54 & 0.824 & 1.192 \\
\hline & $5-32 \mathrm{E}$ & $1.67 \times 10^{-4}$ & 50 & 31 & 144 & 6 & 244 & 58 & 0.710 & 1.195 \\
\hline & $5-33 \mathrm{~A}$ & $2.72 \times 10^{-4}$ & 55 & 29 & 153 & 15 & 268 & 57 & 0.556 & 1.205 \\
\hline & $5-33 B$ & $2.92 \times 10^{-4}$ & 52 & 29 & 148 & 10 & 255 & 59 & 0.491 & 1.207 \\
\hline & $5-33 C$ & $2.37 \times 10^{-4}$ & 47 & 32 & 148 & 17 & 261 & 53 & 0.507 & 1.179 \\
\hline & $5-33 D$ & $2.13 \times 10^{-4}$ & 56 & 31 & 151 & 9 & 255 & 57 & 0.516 & 1.185 \\
\hline & $5-33 E$ & $2.26 \times 10^{-4}$ & 57 & 33 & 153 & 10 & 257 & 55 & 0.441 & 1.180 \\
\hline & $5-34 \mathrm{~A}$ & $1.41 \times 10^{-4}$ & 70 & 29 & 162 & 4 & 258 & 61 & 0.799 & 1.216 \\
\hline & $5-34 \mathrm{~B}$ & $1.51 \times 10^{-4}$ & 74 & 29 & 165 & 1 & 256 & 61 & 0.867 & 1.200 \\
\hline & $5-34 \mathrm{C}$ & $1.17 \times 10^{-4}$ & 52 & 27 & 148 & 10 & 257 & 61 & 0.795 & 1.209 \\
\hline & $5-35 \mathrm{~A}$ & $1.24 \times 10^{-4}$ & 55 & 30 & 145 & 1 & 238 & 60 & 0.753 & 1.189 \\
\hline & $5-35 B$ & $1.31 \times 10^{-4}$ & 67 & 29 & 337 & 1 & 244 & 61 & 0.725 & 1.190 \\
\hline & $5-35 C$ & $1.34 \times 10^{-4}$ & 67 & 32 & 157 & 1 & 248 & 58 & 0.729 & 1.205 \\
\hline & $5-35 \mathrm{D}$ & $1.17 \times 10^{-4}$ & 77 & 33 & 344 & 6 & 245 & 57 & 0.692 & 1.197 \\
\hline & $5-35 \mathrm{E}$ & $1.31 \times 10^{-4}$ & 67 & 32 & 157 & 1 & 248 & 58 & 0.713 & 1.190 \\
\hline & $5-36 \mathrm{~A}$ & $1.41 \times 10^{-4}$ & 50 & 27 & 147 & 13 & 260 & 59 & 0.753 & 1.183 \\
\hline & $5-36 B$ & $1.32 \times 10^{-4}$ & 49 & 25 & 143 & 9 & 252 & 63 & 0.630 & 1.178 \\
\hline & $5-36 C$ & $1.44 \times 10^{-4}$ & 47 & 21 & 142 & 14 & 262 & 64 & 0.717 & 1.177 \\
\hline & $5-36 \mathrm{D}$ & $1.34 \times 10^{-4}$ & 46 & 27 & 140 & 8 & 246 & 62 & 0.670 & 1.184 \\
\hline & $5-36 \mathrm{E}$ & $1.05 \times 10^{-4}$ & 59 & 23 & 153 & 10 & 264 & 65 & 0.612 & 1.170 \\
\hline & $5-37 \mathrm{~A}$ & $1.34 \times 10^{-4}$ & 53 & 28 & 154 & 18 & 273 & 56 & 0.811 & 1.195 \\
\hline & $5-37 \mathrm{~B}$ & $1.27 \times 10^{-4}$ & 57 & 24 & 153 & 15 & 273 & 62 & 0.826 & 1.174 \\
\hline & $5-37 C$ & $1.49 \times 10^{-4}$ & 66 & 24 & 165 & 19 & 289 & 59 & 0.862 & 1.156 \\
\hline & 5-37D & $1.23 \times 10^{-4}$ & 57 & 29 & 157 & 19 & 276 & 55 & 0.795 & 1.166 \\
\hline & $5-38 \mathrm{~A}$ & $1.46 \times 10^{-4}$ & 47 & 30 & 147 & 16 & 261 & 55 & 0.718 & 1.187 \\
\hline & $5-38 B$ & $1.40 \times 10^{-4}$ & 51 & 27 & 148 & 15 & 264 & 59 & 0.660 & 1.170 \\
\hline & $5-38 \mathrm{C}$ & $1.23 \times 10^{-4}$ & 52 & 30 & 152 & 18 & 268 & 54 & 0.772 & 1.176 \\
\hline
\end{tabular}

[Continued next page] 
Table A1 [cont.]: Values $(\mathrm{Km}$, in $\mathrm{SI})$ and Directions $\left(\mathrm{D}=\right.$ Declination, I = Inclination, in degrees $\left.{ }^{\circ}\right)$ of the principal susceptibilities $\left(K_{\max }, K_{\text {int }}\right.$, and $\left.K_{\min }\right)$ of samples from Shiroyama lava; $T$ : shape parameter $(T>0$ oblate, $T<0$ prolate); $P^{\prime}$ : degree of anisotropy.

\begin{tabular}{|c|c|c|c|c|c|c|c|c|c|c|}
\hline \multirow{2}{*}{ Site } & \multirow{2}{*}{ Sample name } & \multirow{2}{*}{$\mathrm{Km}$} & \multicolumn{2}{|c|}{$K_{\max }$} & \multicolumn{2}{|c|}{$K_{\text {int }}$} & \multicolumn{2}{|c|}{$K_{\min }$} & \multirow[t]{2}{*}{$T$} & \multirow[t]{2}{*}{$P^{\prime}$} \\
\hline & & & $\mathrm{D}$ & I & $\mathrm{D}$ & I & $\mathrm{D}$ & I & & \\
\hline \multirow[t]{36}{*}{6} & $6-41 \mathrm{~A}$ & $9.21 \times 10^{-5}$ & 96 & 39 & 352 & 16 & 245 & 47 & 0.928 & 1.130 \\
\hline & $6-41 B$ & $7.99 \times 10^{-5}$ & 55 & 45 & 151 & 5 & 246 & 45 & 0.810 & 1.131 \\
\hline & $6-41 C$ & $9.22 \times 10^{-5}$ & 79 & 44 & 343 & 7 & 245 & 45 & 0.746 & 1.121 \\
\hline & $6-41 \mathrm{D}$ & $6.93 \times 10^{-5}$ & 87 & 45 & 345 & 12 & 243 & 43 & 0.788 & 1.121 \\
\hline & $6-42 \mathrm{~A}$ & $7.70 \times 10^{-5}$ & 50 & 44 & 151 & 12 & 252 & 44 & 0.741 & 1.152 \\
\hline & $6-42 B$ & $7.86 \times 10^{-5}$ & 68 & 49 & 160 & 2 & 251 & 41 & 0.580 & 1.149 \\
\hline & $6-42 C$ & $7.85 \times 10^{-5}$ & 61 & 46 & 157 & 5 & 252 & 44 & 0.671 & 1.147 \\
\hline & $6-42 \mathrm{D}$ & $7.59 \times 10^{-5}$ & 84 & 49 & 348 & 5 & 254 & 41 & 0.698 & 1.155 \\
\hline & $6-42 E$ & $7.86 \times 10^{-5}$ & 63 & 47 & 156 & 3 & 249 & 43 & 0.637 & 1.166 \\
\hline & $6-43 \mathrm{~A}$ & $7.44 \times 10^{-5}$ & 75 & 40 & 340 & 6 & 243 & 49 & 0.778 & 1.154 \\
\hline & $6-43 B$ & $8.27 \times 10^{-5}$ & 66 & 42 & 335 & 1 & 244 & 48 & 0.692 & 1.135 \\
\hline & $6-43 C$ & $7.43 \times 10^{-5}$ & 71 & 38 & 334 & 8 & 234 & 51 & 0.824 & 1.135 \\
\hline & $6-44 \mathrm{~A}$ & $7.56 \times 10^{-5}$ & 92 & 45 & 349 & 12 & 247 & 43 & 0.649 & 1.129 \\
\hline & $6-44 B$ & $8.23 \times 10^{-5}$ & 101 & 45 & 355 & 16 & 251 & 41 & 0.725 & 1.130 \\
\hline & $6-44 C$ & $8.75 \times 10^{-5}$ & 96 & 45 & 356 & 10 & 257 & 43 & 0.729 & 1.091 \\
\hline & $6-44 \mathrm{D}$ & $9.49 \times 10^{-5}$ & 93 & 45 & 350 & 12 & 248 & 42 & 0.442 & 1.119 \\
\hline & $6-44 \mathrm{E}$ & $7.50 \times 10^{-5}$ & 95 & 46 & 353 & 11 & 253 & 41 & 0.640 & 1.117 \\
\hline & $6-45 \mathrm{~A}$ & $8.01 \times 10^{-5}$ & 115 & 38 & 5 & 23 & 251 & 43 & 0.738 & 1.144 \\
\hline & $6-45 B$ & $8.07 \times 10^{-5}$ & 102 & 46 & 359 & 13 & 258 & 41 & 0.704 & 1.126 \\
\hline & $6-45 C$ & $7.28 \times 10^{-5}$ & 100 & 51 & 353 & 13 & 253 & 36 & 0.667 & 1.126 \\
\hline & $6-45 \mathrm{D}$ & $6.35 \times 10^{-5}$ & 74 & 50 & 170 & 4 & 264 & 39 & 0.746 & 1.102 \\
\hline & $6-46 \mathrm{~A}$ & $7.70 \times 10^{-5}$ & 105 & 39 & 1 & 17 & 252 & 46 & 0.813 & 1.130 \\
\hline & $6-46 B$ & $7.90 \times 10^{-5}$ & 72 & 43 & 342 & 1 & 251 & 47 & 0.741 & 1.134 \\
\hline & $6-46 C$ & $7.73 \times 10^{-5}$ & 63 & 42 & 155 & 2 & 247 & 48 & 0.752 & 1.159 \\
\hline & $6-46 \mathrm{D}$ & $7.57 \times 10^{-5}$ & 103 & 40 & 359 & 16 & 252 & 45 & 0.762 & 1.147 \\
\hline & $6-46 E$ & $7.72 \times 10^{-5}$ & 94 & 42 & 352 & 12 & 249 & 45 & 0.734 & 1.124 \\
\hline & $6-47 \mathrm{~A}$ & $8.02 \times 10^{-5}$ & 66 & 43 & 331 & 5 & 235 & 46 & 0.638 & 1.152 \\
\hline & $6-47 B$ & $8.93 \times 10^{-5}$ & 72 & 41 & 337 & 6 & 240 & 49 & 0.573 & 1.185 \\
\hline & $6-47 C$ & $7.39 \times 10^{-5}$ & 49 & 44 & 140 & 1 & 231 & 46 & 0.619 & 1.116 \\
\hline & $6-47 D$ & $8.85 \times 10^{-5}$ & 84 & 45 & 342 & 11 & 242 & 42 & 0.511 & 1.180 \\
\hline & $6-47 E$ & $9.00 \times 10^{-5}$ & 75 & 48 & 338 & 7 & 242 & 42 & 0.464 & 1.168 \\
\hline & $6-48 \mathrm{~A}$ & $6.88 \times 10^{-5}$ & 83 & 48 & 345 & 7 & 249 & 41 & 1.150 & 1.162 \\
\hline & $6-48 B$ & $6.90 \times 10^{-5}$ & 70 & 49 & 339 & 0 & 249 & 41 & 0.712 & 1.182 \\
\hline & $6-48 C$ & $7.09 \times 10^{-5}$ & 72 & 49 & 339 & 2 & 247 & 41 & 0.715 & 1.174 \\
\hline & $6-48 \mathrm{D}$ & $6.80 \times 10^{-5}$ & 66 & 50 & 157 & 1 & 248 & 40 & 0.729 & 1.167 \\
\hline & $6-48 \mathrm{E}$ & $6.90 \times 10^{-5}$ & 67 & 50 & 159 & 1 & 250 & 40 & 0.838 & 1.183 \\
\hline \multirow[t]{13}{*}{8} & 8 & $4.73 \times 10^{-5}$ & 36 & 30 & 129 & 5 & 227 & 60 & 10 & 1.130 \\
\hline & $8-81 B$ & $3.95 \times 10^{-5}$ & 42 & 19 & 181 & 65 & 306 & 15 & 0.477 & 1.026 \\
\hline & $8-81 C$ & $2.75 \times 10^{-5}$ & 55 & 46 & 298 & 23 & 191 & 34 & -0.378 & 1.119 \\
\hline & $8-82 \mathrm{~A}$ & $3.48 \times 10^{-5}$ & 51 & 55 & 145 & 3 & 237 & 35 & -0.261 & 1.057 \\
\hline & $8-82 B$ & $3.80 \times 10^{-5}$ & 74 & 54 & 192 & 19 & 294 & 29 & 0.851 & 1.054 \\
\hline & $8-82 C$ & $4.61 \times 10^{-5}$ & 62 & 44 & 188 & 32 & 299 & 30 & 0.881 & 1.299 \\
\hline & $8-82 \mathrm{D}$ & $3.94 \times 10^{-5}$ & 31 & 8 & 124 & 20 & 280 & 69 & 0.669 & 1.043 \\
\hline & $8-83 \mathrm{~A}$ & $4.42 \times 10^{-5}$ & 204 & 26 & 55 & 60 & 301 & 14 & -0.110 & 1.091 \\
\hline & $8-83 B$ & $3.82 \times 10^{-5}$ & 101 & 77 & 205 & 3 & 296 & 12 & 0.242 & 1.043 \\
\hline & $8-83 C$ & $4.05 \times 10^{-5}$ & 134 & 70 & 31 & 5 & 299 & 19 & 0.228 & 1.067 \\
\hline & $8-84 \mathrm{~A}$ & $4.13 \times 10^{-5}$ & 28 & 41 & 242 & 44 & 134 & 18 & 0.085 & 1.041 \\
\hline & 8-84B & $5.40 \times 10^{-5}$ & 20 & 47 & 176 & 40 & 276 & 12 & -0.093 & 1.087 \\
\hline & $8-84 \mathrm{C}$ & $4.10 \times 10^{-5}$ & 48 & 38 & 210 & 50 & 311 & 9 & -0.122 & 1.048 \\
\hline
\end{tabular}

[Continued next page] 
Table A1 [cont.]: Values ( $\mathrm{Km}$, in $\mathrm{SI})$ and Directions $\left(\mathrm{D}=\right.$ Declination, I = Inclination, in degrees $\left.{ }^{\circ}\right)$ of the principal susceptibilities $\left(K_{\max }, K_{\mathrm{int}}\right.$, and $\left.K_{\min }\right)$ of samples from Shiroyama lava; $T$ : shape parameter $(T>0$ oblate, $T<0$ prolate); $P^{\prime}$ : degree of anisotropy.

\begin{tabular}{|c|c|c|c|c|c|c|c|c|c|c|}
\hline \multirow[t]{2}{*}{ Site } & \multirow{2}{*}{ Sample name } & \multirow{2}{*}{$\mathrm{Km}$} & \multicolumn{2}{|c|}{$K_{\max }$} & \multicolumn{2}{|c|}{$K_{\text {int }}$} & \multicolumn{2}{|c|}{$K_{\min }$} & \multirow[t]{2}{*}{$T$} & \multirow[t]{2}{*}{$P^{\prime}$} \\
\hline & & & $\mathrm{D}$ & I & $\mathrm{D}$ & I & $\mathrm{D}$ & I & & \\
\hline \multirow[t]{16}{*}{8} & $8-84 \mathrm{D}$ & $4.46 \times 10^{-5}$ & 35 & 25 & 211 & 65 & 304 & 2 & -0.383 & 1.058 \\
\hline & $8-85 A$ & $3.45 \times 10^{-5}$ & 22 & 53 & 200 & 37 & 290 & 1 & -0.170 & 1.056 \\
\hline & $8-85 B$ & $4.92 \times 10^{-5}$ & 40 & 29 & 202 & 60 & 306 & 7 & 0.728 & 1.053 \\
\hline & $8-85 C$ & $3.99 \times 10^{-5}$ & 27 & 25 & 157 & 54 & 285 & 24 & -0.332 & 1.048 \\
\hline & $8-85 \mathrm{D}$ & $3.85 \times 10^{-5}$ & 34 & 56 & 180 & 29 & 279 & 16 & -0.196 & 1.035 \\
\hline & $8-86 A$ & $4.14 \times 10^{-5}$ & 165 & 63 & 353 & 27 & 261 & 3 & 0.080 & 1.029 \\
\hline & $8-86 B$ & $4.48 \times 10^{-5}$ & 7 & 47 & 226 & 36 & 120 & 20 & -0.197 & 1.031 \\
\hline & $8-87 \mathrm{~A}$ & $3.52 \times 10^{-5}$ & 200 & 69 & 47 & 19 & 314 & 9 & 0.471 & 1.038 \\
\hline & $8-87 \mathrm{~B}$ & $4.96 \times 10^{-5}$ & 209 & 49 & 351 & 35 & 95 & 20 & -0.783 & 1.100 \\
\hline & $8-87 \mathrm{C}$ & $3.62 \times 10^{-5}$ & 50 & 64 & 179 & 17 & 275 & 19 & -0.180 & 1.038 \\
\hline & 8-87D & $4.07 \times 10^{-5}$ & 153 & 77 & 24 & 8 & 293 & 10 & 0.312 & 1.156 \\
\hline & $8-87 \mathrm{E}$ & $3.77 \times 10^{-5}$ & 48 & 38 & 195 & 47 & 304 & 17 & 0.389 & 1.049 \\
\hline & $8-88 \mathrm{~A}$ & $4.51 \times 10^{-5}$ & 179 & 31 & 59 & 40 & 294 & 35 & 0.592 & 1.054 \\
\hline & $8-88 B$ & $4.62 \times 10^{-5}$ & 140 & 60 & 43 & 4 & 311 & 29 & 0.369 & 1.048 \\
\hline & $8-88 \mathrm{C}$ & $5.14 \times 10^{-5}$ & 190 & 14 & 324 & 71 & 97 & 13 & -0.532 & 1.137 \\
\hline & $8-88 \mathrm{D}$ & $4.46 \times 10^{-5}$ & 50 & 39 & 185 & 42 & 299 & 24 & 0.479 & 1.050 \\
\hline \multirow[t]{26}{*}{9} & $1 \mathrm{~A}$ & $6.59 \times 10^{-5}$ & 306 & 55 & 120 & 35 & 212 & 3 & -0.635 & 1.183 \\
\hline & $9-71 \mathrm{~B}$ & $6.70 \times 10^{-5}$ & 136 & 53 & 328 & 36 & 234 & 6 & 0.714 & 1.144 \\
\hline & $9-71 \mathrm{C}$ & $4.21 \times 10^{-5}$ & 198 & 73 & 315 & 8 & 48 & 15 & 0.756 & 1.045 \\
\hline & $9-71 \mathrm{D}$ & $4.49 \times 10^{-5}$ & 182 & 58 & 312 & 22 & 52 & 22 & 0.740 & 1.024 \\
\hline & $9-71 \mathrm{E}$ & $7.50 \times 10^{-5}$ & 154 & 66 & 339 & 24 & 248 & 2 & 0.609 & 1.069 \\
\hline & $9-72 \mathrm{~A}$ & $4.66 \times 10^{-5}$ & 334 & 41 & 222 & 23 & 111 & 40 & -0.665 & 1.087 \\
\hline & $9-73 \mathrm{~A}$ & $5.87 \times 10^{-5}$ & 78 & 8 & 340 & 46 & 176 & 42 & 0.001 & 1.036 \\
\hline & $9-73 B$ & $8.75 \times 10^{-5}$ & 291 & 54 & 116 & 36 & 24 & 2 & -0.267 & 1.012 \\
\hline & $9-74 \mathrm{~A}$ & $4.28 \times 10^{-5}$ & 313 & 9 & 206 & 62 & 47 & 27 & -0.342 & 1.021 \\
\hline & $9-74 \mathrm{~B}$ & $2.93 \times 10^{-5}$ & 327 & 37 & 226 & 14 & 119 & 50 & -0.384 & 1.032 \\
\hline & $9-75 \mathrm{~A}$ & $6.09 \times 10^{-5}$ & 203 & 21 & 335 & 60 & 105 & 20 & 0.659 & 1.057 \\
\hline & $9-75 B$ & $8.54 \times 10^{-5}$ & 197 & 17 & 304 & 42 & 90 & 43 & 0.608 & 1.236 \\
\hline & $9-76 \mathrm{~A}$ & $4.45 \times 10^{-5}$ & 339 & 37 & 131 & 49 & 238 & 14 & 0.275 & 1.028 \\
\hline & $9-76 \mathrm{~B}$ & $6.15 \times 10^{-5}$ & 328 & 3 & 233 & 63 & 59 & 27 & 0.078 & 1.085 \\
\hline & $9-76 \mathrm{C}$ & $4.40 \times 10^{-5}$ & 318 & 43 & 154 & 46 & 56 & 8 & -0.303 & 1.026 \\
\hline & $9-76 \mathrm{D}$ & $4.48 \times 10^{-5}$ & 176 & 16 & 290 & 55 & 77 & 31 & 0.055 & 1.093 \\
\hline & $9-77 \mathrm{~A}$ & $5.90 \times 10^{-5}$ & 127 & 83 & 334 & 6 & 244 & 3 & 0.842 & 1.077 \\
\hline & $9-77 \mathrm{~B}$ & $4.42 \times 10^{-5}$ & 350 & 8 & 194 & 82 & 81 & 3 & 0.368 & 1.025 \\
\hline & $9-77 \mathrm{C}$ & $7.21 \times 10^{-5}$ & 206 & 12 & 37 & 78 & 297 & 2 & -0.554 & 1.102 \\
\hline & $9-77 \mathrm{D}$ & $5.62 \times 10^{-5}$ & 134 & 13 & 342 & 75 & 225 & 7 & 0.495 & 1.034 \\
\hline & $9-77 \mathrm{E}$ & $5.22 \times 10^{-5}$ & 144 & 36 & 236 & 2 & 329 & 54 & -0.955 & 1.074 \\
\hline & $9-78 \mathrm{~A}$ & $4.44 \times 10^{-5}$ & 125 & 33 & 266 & 50 & 21 & 20 & 0.026 & 1.038 \\
\hline & $9-78 \mathrm{~B}$ & $4.72 \times 10^{-5}$ & 100 & 50 & 266 & 39 & 2 & 7 & -0.216 & 1.047 \\
\hline & $9-78 \mathrm{C}$ & $4.34 \times 10^{-5}$ & 337 & 33 & 155 & 57 & 246 & 1 & -0.399 & 1.041 \\
\hline & $9-78 \mathrm{D}$ & $4.94 \times 10^{-5}$ & 329 & 15 & 191 & 70 & 63 & 13 & 0.410 & 1.024 \\
\hline & $9-78 \mathrm{E}$ & $5.85 \times 10^{-5}$ & 328 & 14 & 157 & 76 & 59 & 2 & 0.554 & 1.051 \\
\hline
\end{tabular}


Table A2: Results of FTIR analyses of Shiroyama lava

\begin{tabular}{|c|c|c|c|c|c|c|c|c|c|}
\hline Site & & Lithofacies & $\begin{array}{l}\text { Absorbance } \\
1630 \mathrm{~cm}^{-1}\end{array}$ & $\begin{array}{l}\text { Absorbance } \\
3550 \mathrm{~cm}^{-1}\end{array}$ & $\begin{array}{l}\text { Thickness } \\
(\mathrm{cm})\end{array}$ & $\begin{array}{l}\mathrm{H}_{2} \mathrm{O}_{\mathrm{m}} \\
\text { (wt. \%) }\end{array}$ & $\begin{array}{c}\mathrm{OH} \\
(\text { wt. \%) }\end{array}$ & $\begin{array}{l}\mathrm{H} 2 \mathrm{Ot} \\
\text { (wt. \%) }\end{array}$ & $\frac{\mathrm{H}_{2} \mathrm{O}_{\mathrm{m}}}{\mathrm{OH}}$ \\
\hline \multirow[t]{44}{*}{1} & \multirow[t]{6}{*}{ OBS-1 } & \multirow{6}{*}{$\begin{array}{c}\text { Obsidian } \\
\text { (Massive } \\
\text { part) }\end{array}$} & 0.27 & 1.16 & 0.012 & 0.31 & 0.51 & 0.83 & 0.61 \\
\hline & & & 0.27 & 1.16 & 0.012 & 0.32 & 0.51 & 0.83 & 0.62 \\
\hline & & & 0.29 & 1.17 & 0.012 & 0.34 & 0.50 & 0.84 & 0.68 \\
\hline & & & 0.29 & 1.18 & 0.012 & 0.34 & 0.50 & 0.84 & 0.67 \\
\hline & & & 0.27 & 1.16 & 0.012 & 0.31 & 0.52 & 0.83 & 0.61 \\
\hline & & & 0.26 & 1.16 & 0.012 & 0.30 & 0.52 & 0.83 & 0.58 \\
\hline & \multirow[t]{6}{*}{ OBS-3 } & & 0.27 & 1.22 & 0.013 & 0.30 & 0.53 & 0.83 & 0.56 \\
\hline & & & 0.26 & 1.22 & 0.013 & 0.29 & 0.54 & 0.83 & 0.54 \\
\hline & & & 0.26 & 1.20 & 0.013 & 0.29 & 0.52 & 0.82 & 0.56 \\
\hline & & & 0.26 & 1.21 & 0.013 & 0.29 & 0.53 & 0.82 & 0.55 \\
\hline & & & 0.26 & 1.19 & 0.013 & 0.29 & 0.52 & 0.81 & 0.57 \\
\hline & & & 0.27 & 1.19 & 0.013 & 0.30 & 0.51 & 0.81 & 0.59 \\
\hline & \multirow[t]{6}{*}{ OBS-2 } & \multirow{6}{*}{$\begin{array}{l}\text { Obsidian } \\
\text { (Healed- } \\
\text { fracture } \\
\text { part) }\end{array}$} & 0.24 & 1.13 & 0.013 & 0.26 & 0.50 & 0.77 & 0.52 \\
\hline & & & 0.23 & 1.12 & 0.013 & 0.26 & 0.50 & 0.76 & 0.51 \\
\hline & & & 0.23 & 1.12 & 0.013 & 0.26 & 0.51 & 0.77 & 0.52 \\
\hline & & & 0.25 & 1.12 & 0.013 & 0.28 & 0.49 & 0.76 & 0.57 \\
\hline & & & 0.23 & 1.12 & 0.013 & 0.26 & 0.50 & 0.76 & 0.52 \\
\hline & & & 0.24 & 1.12 & 0.013 & 0.26 & 0.50 & 0.76 & 0.53 \\
\hline & \multirow[t]{10}{*}{ OBS-4 } & & 0.19 & 1.02 & 0.012 & 0.22 & 0.52 & 0.75 & 0.43 \\
\hline & & & 0.19 & 1.00 & 0.012 & 0.23 & 0.50 & 0.73 & 0.45 \\
\hline & & & 0.23 & 0.99 & 0.012 & 0.27 & 0.45 & 0.72 & 0.61 \\
\hline & & & 0.23 & 0.98 & 0.012 & 0.27 & 0.44 & 0.71 & 0.62 \\
\hline & & & 0.23 & 1.03 & 0.012 & 0.27 & 0.48 & 0.75 & 0.56 \\
\hline & & & 0.21 & 1.02 & 0.012 & 0.25 & 0.49 & 0.74 & 0.50 \\
\hline & & & 0.21 & 1.01 & 0.012 & 0.25 & 0.49 & 0.74 & 0.51 \\
\hline & & & 0.24 & 1.02 & 0.012 & 0.29 & 0.46 & 0.74 & 0.63 \\
\hline & & & 0.23 & 1.04 & 0.012 & 0.28 & 0.48 & 0.76 & 0.58 \\
\hline & & & 0.23 & 1.02 & 0.012 & 0.28 & 0.47 & 0.74 & 0.59 \\
\hline & \multirow[t]{6}{*}{ OBS-5 } & & 0.57 & 1.38 & 0.010 & 0.82 & 0.38 & 1.20 & 2.14 \\
\hline & & & 0.57 & 1.39 & 0.010 & 0.81 & 0.39 & 1.20 & 2.09 \\
\hline & & & 0.57 & 1.40 & 0.010 & 0.81 & 0.40 & 1.21 & 2.00 \\
\hline & & & 0.57 & 1.40 & 0.010 & 0.81 & 0.41 & 1.22 & 1.97 \\
\hline & & & 0.57 & 1.38 & 0.010 & 0.80 & 0.39 & 1.20 & 2.04 \\
\hline & & & 0.57 & 1.39 & 0.010 & 0.82 & 0.39 & 1.21 & 2.09 \\
\hline & \multirow[t]{10}{*}{ OBS-6 } & & 0.34 & 1.10 & 0.012 & 0.40 & 0.40 & 0.80 & 1.01 \\
\hline & & & 0.34 & 1.09 & 0.012 & 0.41 & 0.39 & 0.79 & 1.05 \\
\hline & & & 0.33 & 1.11 & 0.012 & 0.39 & 0.42 & 0.81 & 0.94 \\
\hline & & & 0.34 & 1.11 & 0.012 & 0.40 & 0.41 & 0.81 & 0.98 \\
\hline & & & 0.34 & 1.12 & 0.012 & 0.40 & 0.41 & 0.81 & 0.97 \\
\hline & & & 0.34 & 1.11 & 0.012 & 0.40 & 0.41 & 0.81 & 0.98 \\
\hline & & & 0.34 & 1.12 & 0.012 & 0.40 & 0.41 & 0.81 & 0.97 \\
\hline & & & 0.34 & 1.12 & 0.012 & 0.40 & 0.41 & 0.81 & 0.98 \\
\hline & & & 0.34 & 1.12 & 0.012 & 0.40 & 0.42 & 0.82 & 0.96 \\
\hline & & & 0.34 & 1.12 & 0.012 & 0.41 & 0.41 & 0.82 & 0.98 \\
\hline \multirow[t]{5}{*}{2} & & Vesicular & 0.12 & 0.40 & 0.015 & 0.11 & 0.12 & 0.23 & 0.96 \\
\hline & & & 0.13 & 0.42 & 0.015 & 0.12 & 0.12 & 0.24 & 0.96 \\
\hline & & & 0.11 & 0.40 & 0.015 & 0.11 & 0.12 & 0.23 & 0.90 \\
\hline & & & 0.17 & 0.46 & 0.015 & 0.16 & 0.10 & 0.26 & 1.65 \\
\hline & & & 0.12 & 0.42 & 0.015 & 0.11 & 0.12 & 0.24 & 0.95 \\
\hline \multirow[t]{3}{*}{6} & & Vesicular & 0.16 & 0.31 & 0.006 & 0.37 & 0.08 & 0.45 & 4.64 \\
\hline & & & 0.16 & 0.31 & 0.006 & 0.37 & 0.07 & 0.45 & 4.96 \\
\hline & & & 0.16 & 0.31 & 0.006 & 0.37 & 0.08 & 0.45 & 4.92 \\
\hline \multirow[t]{7}{*}{9} & & Vesicular & 0.07 & 0.17 & 0.004 & 0.22 & 0.11 & 0.34 & 1.92 \\
\hline & & & 0.07 & 0.17 & 0.004 & 0.22 & 0.12 & 0.34 & 1.90 \\
\hline & & & 0.13 & 0.31 & 0.008 & 0.25 & 0.10 & 0.35 & 2.44 \\
\hline & & & 0.13 & 0.31 & 0.008 & 0.25 & 0.11 & 0.35 & 2.34 \\
\hline & & & 0.13 & 0.31 & 0.008 & 0.25 & 0.10 & 0.35 & 2.43 \\
\hline & & & 0.14 & 0.33 & 0.008 & 0.26 & 0.12 & 0.38 & 2.20 \\
\hline & & & 0.14 & 0.34 & 0.008 & 0.26 & 0.12 & 0.38 & 2.17 \\
\hline
\end{tabular}

